\title{
EL INDULTO COMO ACTO DEL GOBIERNO: UNA PERSPECTIVA CONSTITUCIONAL. (Especial análisis del "caso Liaño")
}

\author{
JUAN LUIS PÉREZ FRANCESCH \\ Profesor titular de Derecho Constitucional \\ Departament de Ciència Política i de Dret Públic \\ Universitat Autònoma de Barcelona
}

FERNANDO DOMINGUEZ GARCÍA Investigador. Departamento de Derecho Instituto Universitario Europeo 


\section{SUMARIO}

I. Introducción. II. El indulto como acto del Gobierno. 1. El indulto en el seno del Estado de Derecho y de la Monarquía Parlamentaria. 2. Marco legal y naturaleza juridica del indulto. 2.1. Regulación vigente. 22. Procedimiento. 2.3. Límites. 2.4. Controles. III. EL "CASO LIAÑo». 1. Desarrollo del caso. 1.1. Antecedentes. Del "caso Sogecable» al expediente de indulto. 1.2. El Real Decreto de indulto. 1.3. El auto de la Sala Segunda delTribunal Supremo y el requerimiento de incompetencia instado por el Gobierno. 1.4. La sentencia del Tribunal de Conflictos de Jurisdicción. 1.5. A modo de conclusión. 2. Aspectos del "caso Liaño" que ponen de manifiesto las deficiencias de la actual ley del indulto. IV. Propuestas PARA LA REFORMA DE LA LEY DEL INDULTO. V. BiBLIOGRAFÍA. 


\title{
EL INDULTO COMO ACTO DEL GOBIERNO: UNA PERSPECTIVA CONSTITUCIONAL. (Especial análisis del «caso Liaño»)
}

POR

\author{
JUAN LUIS PÉREZ FRANCESCH \\ Profesor titular de Derecho Constitucional \\ Departament de Ciència Política i de Dret Públic \\ Universitat Autònoma de Barcelona
}

\author{
FERNANDO DOMÍNGUEZ GARCÍA \\ Investigador. Departamento de Derecho \\ Instituto Universitario Europeo
}

\section{INTRODUCCIÓN}

El derecho de gracia es un concepto jurídico anterior a la configuración del Estado de Derecho y de la Monarquía Parlamentaria tal y como hoy en día los conocemos. Si bien la propia existencia del derecho de gracia es una reminiscencia histórica, que tiene su apogeo en las monarquías absolutas y en el Antiguo Régimen, es conveniente hacer un esfuerzo para ubicarlo en el seno del Estado constitucional actual $y$, en el caso español, en coherencia con los principios constitucionales de la monarquía parlamentaria y del Estado de Derecho. No 
hay que olvidar, como afirma Zúñiga Urbina, que «en el contexto de la democracia constitucional los institutos de clemencia deben ser penetrados por el principio democrático, por la sujeción a un principio de legalidad y teniendo como limitación los derechos humanos" 1 .

Según el ordenamiento jurídico vigente, la responsabilidad de indultar recae en el Gobierno, potestad que se exterioriza por medio de un Real Decreto acordado en Consejo de Ministros y firmado por el Rey (art. 62.f y 62.i CE), con el refrendo del Ministro de Justicia (art. $64 \mathrm{CE}$ ). Si bien es un acto en su esencia discrecional, es decir, en lo referente a determinar si se indulta o no a cierta persona, como todo acto discrecional contiene diversos componentes reglados que se encuentran dispersos en diferentes normas juridicas, siendo la más importante de ellas, sin duda, la Ley provisional de 18 de junio de 1870.

La problemática jurídica en torno al concepto del derecho de gracia ha tomado un especial relieve en los últimos tiempos, especialmente por la concesión del indulto a Javier Gómez de Liaño, magistrado condenado por prevaricación continuada. Este indulto, aparte de ríos de tinta que ha hecho correr en los medios de comunicación, ha provocado una polémica jurídica sin precedentes, cuyo fruto son las diversas resoluciones que se han dictado?.

En el presente trabajo se analiza el indulto como acto del Gobierno, y su encaje problemático en el marco del principio de separación de poderes, en tanto que elemento estructural del Estado de Derecho. No obstante, no pretendemos hacer un análisis puro ni dogmático del derecho de gracia, sino fundamentalmente extraer consecuencias generales del examen de un caso concreto (aunque especialmente relevante) como es el indulto a Gómez de Liaño.

1 ZúNíga UrBina, Francisco, "Amnistía ante la jurisprudencia (Derechos humanos como límite al ejercicio de la soberania)", Revista de Derecho Político, núm. 42, 1996, pág. 378.

2 Para abreviar utilizaremos las siguientes siglas, ordenadas cronológicamente: SC (Sentencia de condena de la Sala Segunda del Tribunal Supremo de 15 de octubre de 1999 al Magistrado Gómez de Liaño por prevaricación continuada), ITS (Informe negativo de la Sala Segunda del Tribunal Supremo, de 14 de junio de 2000 sobre la petición de indulto), DI (Real Decreto 2392/2000, de 1 de diciembre, publicado en el BOE, núm.305, de 21 de diciembre de 2000), Al (Auto de la Sala segunda delTS, de 18 de enero de 2001, sobre la aplicación del indulto), ARI (Auto de la Sala Segunda delTS de 13 de marzo de 2001, ante el requerimiento de incompatencia instado por el Gobierno), STCJ (Sentencia del Tribural de Conflictos de Jurisdicción 6/2001, de 13 de junio). 
Pretender estudiar el "caso Liaño" simplemente como un supuesto de indulto de un delito de prevaricación supondría cuanto menos una actitud ingenua. Existen unos trasfondos empresariales, mediáticos $y$ en última instancia políticos, mezclados con un conjunto de relaciones familiares, que distorsionan notablemente el asunto. La batalla judicial es un acto más de esta guerra donde la batalla mediática se encuentra en primera línea del frente.

Lejos de entrar en polémicas periodísticas, aspiramos a aprovechar el debate de ideas que se ha producido para, juntamente con las resoluciones que se han dictado, intentar formular las propuestas necesarias de cara a una próxima reforma de la Ley del indulto, o en su caso, la elaboración de una nueva ley. El leitmotiv de estas líneas es claro: el "caso Liaño" ha mostrado cómo una regulación legal que deja las manos (casi) libres al Gobierno para ejercer el derecho de gracia puede hacer tambalear cimientos del Estado de Derecho como son la independencia del Poder Judicial o la separación de poderes. Una nueva ley del indulto es, en estos momentos, urgente. Si la propia exposición de motivos de la actual ley de 1870 expresa que es "manifiesto que debe haber una ley con arreglo a cuyas disposiciones la Corona ha de ejercer tan preciosa prerrogativa" podemos añadir que es necesario que las prescripciones de la citada ley estén adaptadas a un Estado social y democrático de Derecho del siglo XXI, así como al principio de la monarquía parlamentaria. $Y$ las bases de la pervivencia del instituto jurídico del indulto deben ser el principio de legalidad $y$, en su caso, el control judicial de sus elementos reglados. El binomio formado entre el principio de legalidad y el control judicial se convierte asi en el hilo conductor del presente trabajo.

\section{EL INDULTO COMO ACTO DEL GOBIERNO}

\section{El indulto en el seno del Estado de Derecho y de la Monarquía Parlamentaria}

En el marco de la Monarquía parlamentaria (art. 1.3 CE y art. 62 CE), no cabe duda de que no estamos ante un acto regio atribuible a su exclusiva voluntad. Lejos de aparecer como una prerrogativa del titular de la Corona ${ }^{3}$, nos hallamos ante un acto del Gobierno que inci-

3 Si bien el perdón se ha ejercido en civilizaciones $y$ épocas diversas, durante etapas absolutistas se intentó hacer ver en el indulto un acto de Justicia 
de en el ejercicio de la potestad jurisdiccional del Estado. Por eso entendemos que no se debería sostener que el indulto es un acto del Rey, si con esta expresión se alude a una cierta capacidad de decisión del monarca. El dilema, sin embargo, surge del hecho de que la Constitución no realiza ninguna referencia al órgano encargado de tomar la decisión que firmará el Rey. La Constitución no atribuye al Gobierno explícitamente la competencia para resolver los expedientes de indulto. López Aguilar ${ }^{4}$ ha entendido que debido a la irresponsabilidad del Rey y en virtud de la institución del refrendo (art. $64 \mathrm{CE}$ ), la competencia corresponde al Gobierno o, en su caso, a los Ministros competentes ${ }^{5}$. Asi también parece haberlo entendido la STCJ al afirmar que: "Del texto de estos preceptos, así como de los contenidos en los artículos 62 f), 64, y 97, se llega a la conclusión de que si bien la concesión de indultos, no generales, es facultad reservada al Monarca, su plasmación formal se efectúa a través de Real Decreto acordado en Consejo de Ministros, a propuesta del de Justicia (expresamente lo afirma el artículo 30 de la Ley de 18 de junio de 1.870), cuyo control puede ejercitarse a través de la Jurisdicción ContenciosoAdministrativa".

Ahora bien, a nuestro entender el artículo $64 \mathrm{CE}$ relativo al refrendo de los actos del Rey no es un título de atribución de competencias materiales, sino de atribución de la competencia para refrendar. Como es conocido, que el Presidente del Gobierno o un Ministro refrende un acto no significa que éste haya sido adoptado necesariamente por

superior a la Ley, que ejercita una gracia que presupone, en cierta manera, un don que proviene de Dios. Aunque en principio perdonar es un acto reservado exclusivamente a Dios (Marcos 2,7), a través del Espíritu Santo, Jesús concede esta gracia a los apóstoles: «A quienes perdonéis los pecados, les quedarán perdonados" (Juan 20, 23). Es decir, un poder divino ejercido por los seres humanos. No es de extrañar, por tanto, que ciertos reyes absolutistas vieran en el ejercicio del indulto una manifestación de una "gracia" divina.

4 Véase, LóPEz AgUILAR, Juan Fernando, "Una reflexión a propósito del control parlamentario del ejercicio del derecho de gracia», Revista de las Cortes Generales, núm. 37, 1996, págs. 329-342.

5 Esta misma línea argumental se observa en el Al: "Si derivamos la concesión del indulto hacia la Corona, no podemos olvidar que los actos del Rey serán siempre refrendados por el Presidente del Gobierno o los Ministros, por lo que la actuación del Gobierno debe ajustarse, en todo, a lo que dispone el artículo 103.1 de la Constitución, al establecer que la Administración Pública sirve con objetividad los intereses generales y actúa con arreglo a los principios de eficacia, jerarquía, descentralización, desconcentración y coordinación, con "sometimiento pleno a la ley y al derecho"". 
quien lo refrenda (y en la Constitución encontramos diversos supuestos en este sentido, como el refrendo del nombramiento de Presidente de una Comunidad Autónoma o de los magistrados del Tribunal Constitucional, entre otros).

La competencia gubernamental para decidir las medidas de gracia proviene de la Ley de 1870 . Un tema distinto es pensar si sería más adecuado que fuera otro órgano o institución del Estado. Consideramos que en este caso no sería inconstitucional una ley que atribuyera, por ejemplo, a las Cortes Generales o al Consejo General del Poder Judicial la competencia para resolver los expedientes de indulto ${ }^{6}$. En este sentido, cabe recordar que la Constitución de la II República reconoció la potestad de conceder la práctica totalidad de los indultos individuales al Tribunal Supremo, a propuesta del Tribunal sentenciador ${ }^{7}$. $Y$ en el proceso de elaboración de la Constitución de 1978, encontramos diversos intentos (minoritarios) de "judicializar» la propuesta de otorgamiento de indultos. El portavoz del Grupo Mixto presentó una enmienda al Anteproyecto que pretendia que los indultos concedidos por el Rey lo fueran a propuesta del Presidente del Tribunal Supremo. Asimismo, en el debate en el seno de la Comisión de Asuntos Constitucionales y Libertades Públicas del Congreso, el diputado Fuejo Lago formuló una enmienda in voce en el mismo sentido, que fue retirada después que el entonces diputado Fraga Iribarne (AP) considerara la enmienda "bien intencionada" pero no adecuada, puesto que "la concesión de los efectos del derecho de gracia evidentemente tiene que ver no sólo con problemas de justicia, sino con problemas políticos en muchos casos" y en consecuencia "la propuesta debe ser la normal en régimen parlamentario».

6 En sentido contrario, LóPEZ AGUILAR, Juan Fernando, «Una reflexión a propósito del control parlamentario del ejercicio del derecho de gracian, en Revista de las Cortes Generales, núm. 37, 1996, págs. 335 y 336, quien entiende que el otorgamiento de indultos corresponde al Gobierno puesto que éste tiene que refrendar los actos del Rey, utilizando el art. 64 CE como un artículo que atribuye competencias materiales, cuando sólo designa los responsables de refrendar los actos del Rey.

7 El art. 102 de la Constitución de la II República Española, de 1931, establecía que «las amnistías sólo podrán ser acordadas por el Parlamento. No se concederán indultos generales. El Tribunal Supremo otorgará los individuales a propuesta del Tribunal Sentenciador, del Fiscal, de la Junta de Prisiones o a petición de parte. En los delitos de extrema gravedad podrá indultar el Presidente de la República, previo informe del Tribunal Supremo y a propuesta del Gobierno responsablen. 
El indulto, por lo tanto, se configura como una decisión del Gobierno y no del Monarca ${ }^{8}$, sin que pueda deducirse esa competencia de la propia Constitución, sino de la ley actualmente vigente.

Más problemático es el encaje del indulto en el actual Estado de Derecho, especialmente en lo concerniente al principio de separación de poderes ${ }^{9}$. En su origen, el derecho de gracia era una manifestación de la unión de todos los poderes del Estado en un rey soberano, por lo que era un acto que no provocaba ningún tipo de conflicto. Sin embargo, en el actual Estado constitucional, que tiene entre sus elementos basilares la separación de poderes, podria entenderse que se trata de una intromisión del poder ejecutivo en el poder judicial. Ahora bien, en el ordenamiento constitucional español hay que tener presente que el Gobierno no ejerce la función reservada al Poder Judicial de juzgar y hacer ejecutar lo juzgado (art. 117.3 CE), puesto que el indulto presupone la existencia de la resolución judicial y la legitimidad del Poder Judicial para dictarla, y no se configura como una nueva instancia o recurso ${ }^{10}$. Se reafirma, por tanto, la existencia de delito, aunque se extinga la responsabilidad penal. Como sintéticamente ha destacado Montserrat Comas d'Argemir, "el indulto no deshace el delito" "1. Por su parte, el Tribunal Constitucional también ha declarado que: "no obstante la extinción de la responsabilidad penal se presupone la existencia de delito" (STC 198/2000, de 24 de julio). Tampoco se cuestiona la aplicación general de la ley penal aprobada por el Poder Legislativo, sino que se excepciona solamente ante un caso particular y particularizado. La propia naturaleza del indulto confirma su respeto hacia las decisiones de las otras instituciones del Estado, puesto que el indulto no es un acto jurisdiccional, sino un acto del Gobierno que deja sin efecto la pena de un delito, incidiendo en el cumplimiento de la decisión judicial inicial, no en la función jurisdiccional12.

8 Aguado Renedo, César, Problemas constitucionales del ejercicio de la potestad de gracia, Civitas, Madrid, 2001, págs. 143-156.

9 Cfr. Aguado Renedo, César, Problemas constitucionales del ejercicio de la potestad de gracia, Civitas, Madrid, 2001, págs. 47-55.

10 EITC ha afirmado que el indulto es un mecanismo «que, sin desvirtuar la obligación constitucional de ejecutar lo juzgado y sin desnaturalizar el contenido del derecho a un proceso sin dilaciones, debe permitir obtener de manera jurídicamente correcta el fin de la no ejecución de la condena" (STC 381/1993, de 20 de diciembre). de 2000.

11 Título del artículo publicado en El Periódico de Cataluña, 5 de diciembre

12 En cambio, en el artículo acabado de citar, "El indulto no deshace el delito", El Periódico de Cataluña, 5 de diciembre de 2000, Montserrat ComAS D'ARGeMIR 
Por el contrario, Enrique Linde Paniagua ${ }^{13}$ ha visto en el otorgamiento del indulto un acto de administración de Justicia realizado por el Gobierno, confundiendo, a nuestro juicio, la finalidad del indulto (la realización de la Justicia material) con la naturaleza del acto, ya que entendemos que el indulto es un acto del Gobierno que incide en las decisiones judiciales, sin innovarlas, es decir, sin crear una nueva resolución judicial. La jurisprudencia delTribunal Supremo se ha situando en la línea que sostenemos: "La cuestión de si la pena debe ser indultada no forma parte del objeto del proceso penal y por lo tanto no caben sobre ella peticiones de los participantes en el mismo. El objeto del proceso penal se limita a la aplicación del derecho dentro de las facultades de los Tribunales según el art. $117 \mathrm{CE}$. La posibilidad de éstos de instar el ejercicio de la gracia no importa aplicación del derecho referente a las pretensiones que les son sometidas, y por lo tanto, cae fuera de la potestad jurisdiccional" (STS de 7 de junio de 1991) ${ }^{14}$. Es decir, si bien formalmente el Gobierno no ejerce funciones de otro poder del Estado sí que se puede afirmar que incide en ellas. En palabras del Al, "el derecho de gracia supone una potestad extraordinaria de intervención de un Poder estatal en el ámbito de competencia de otro, el Judicial», por eso "una vez constitucionalmente admitido, su uso está rodeado de cautelas, con objeto de procurar que esos efectos se produzcan del modo que resulte menos perturbador para la normalidad del orden jurídico". La forma de que no se produzcan perturbaciones en el ejercicio del derecho de gracia es la existencia de una regulación legal y el control judicial de los elementos reglados de esta potestad. El Al ha abundado en esta idea:

«Esta competencia compartida, que otorga la decisión política del indulto al ejecutivo y alTribunal sentenciador la verificación de la legalidad, es decir, de si el acto ha sido dictado "con arreglo a la ley" forma parte de una tradición de casi dos siglos del derecho constitucio-

de forma crítica ha expresado que «la vetusta y cuestionada ley de indulto (...) supone una auténtica intromisión del poder ejecutivo en las decisiones judiciales por razones de oportunidad".

13 LINDE Paniagua, Enrique, "El indulto como acto de administración de Justicia y su judicialización. Problemas, límites y consecuencias», en Teoría y Realidad Constitucional, núm. 5, 2000, págs. 161-175.

14 Al hilo de esta doctrina, el TS ha destacado que ante la negativa de un tribunal a solicitar la concesión de indulto no cabe recurso. Así, en un caso en que según el recurrente el excesivo tiempo transcurrido desde la comisión del delito justificaría la concesión del indulto elTS declaró que: "La cuestión del ejercicio del derecho de gracia es completamente ajena al ámbito casacional» [STS de 11 de noviembre de 2000 (RJ 200016571)]. 
nal español: Todas las constituciones de España desde 1812 han limitado el derecho de gracia a su ejercicio "con arreglo a la ley". Sólo la Ley Orgánica del Estado de 1967 omitió esta referencia a la legalidad.»

De este modo, con los límites trazados por la Ley y con un adecuado control judicial de la legalidad de la medida de gracia, se sientan las bases para su adecuado encaje en la estructura constitucional española. Queda por añadir su finalidad, ya anunciada, de intento de consecución de la Justicia material, que es precisamente la razón por la cual la Constitución acepta la supervivencia de esta institución. Así un acto que podría potencialmente distorsionar la separación de poderes cumple una función constitucional que difícilmente podria ocupar otro instituto jurídico. Como ha recordado Linde Paniagua, la clemencia utiene una importancia capital para la realización del Estado de Derecho, lejos de contradecirlo o ponerlo en crisis" ${ }^{15}$. En la misma línea, el ATC 360/1990 ha destacado que: «Determinadas circunstancias fácticas pueden dar lugar a que, en ocasiones, las penas impuestas como consecuencia de un ilícito pierdan total o parcialmente su significado legal y constitucional. Precisamente para ello existe la figura del indulto que permite compatibilizar las exigencias de la justicia formal con las de la justicia material del caso" (F. 5). Morales Prats sostiene la misma idea, cuando afirma que «el derecho de gracia se configura como instrumento idóneo para la realización de la justicia material, exigencia a la que debe subordinarse el Derecho positivo" ${ }^{16}$.

Pero el principio de legalidad, el control jurisdiccional y el deseo de alcanzar la Justicia material aún no son suficientes para que el indulto sea un instituto jurídico ubicable en un Estado de Derecho moderno. Además hay que tener bien presente que el indulto es una medida de carácter excepcional aplicable a supuestos excepcionales y los motivos de su concesión deben ser deducibles de los preceptos y valores constitucionales $o$, en todo caso, no ser contrarios a los mismos. En esta línea la Consulta de 19 de julio de 199417, de la Fis-

15 LINDE PANIAGUA, Enrique, "La clemencia (amnistía e indulto) a la luz de la jurisprudencia de los tribunales Supremo y Constitucional y del Código Penal de 1995", en Boletín de Información del Ministerio de Justicia, núm. 1823, 15 de junio de 1998, pág. 7 .

16 Morales Prats, Fermín, "Comentario al art. 130", en Comentarios al Nuevo Código Penal, Aranzadi, 2000, pág. 641.

17 Boletín de Información del Ministerio de Justicia, núm. 1732, 25 de enero de 1995. 
calía General del Estado, afirma que el indulto no es un derecho sino una gracia y que en consecuencia tiene un marcado carácter excepcional: "No puede olvidarse que estamos ante una importante matización al principio de separación de poderes. Pero tampoco hay que perder de vista que el indulto se configura como un valioso mecanismo para atemperar el rigor de la Ley y acercarlo a la justicia del caso concreto". De la misma manera el ITS declara que "las razones de justicia o equidad que justificarian renunciar a la ejecución no son un fundamento para que el Poder Ejecutivo pueda modificar discrecionalmente las sentencias del Poder Judicial, sino para eliminar una cierta incompatibilidad entre la rigurosa aplicación de la ley y la valoración ético-social que merece el hecho objeto de la condena". Sin embargo, las afirmaciones anteriores no deberían llevar al extremo de entender, como afirma Linde Paniagua, que "el último reducto, la última esperanza para la realización de la Justicia está en el Gobierno de la nación» 18 , puesto que esta idea parece que acerca el indulto a una nueva instancia, lo que no concuerda con el carácter excepcional del derecho de gracia.

$Y$ sin duda uno de los principios constitucionales que deben regir la concesión de indultos y que adquiere, por su importancia, una entidad propia es la necesidad de motivación. El art. 9.3 CE al garantizar la interdicción de la arbitrariedad de los poderes públicos prohíbe los actos arbitrarios, que no los discrecionales. La capacidad de motivar es lo que diferencia un acto arbitrario de uno discrecional y en consecuencia discrecionalidad no es sinónimo de no motivación, lo que nos lleva a afirmar que la no motivación de un indulto no supone el ejercicio de una facultad discrecional sino la enunciación de un acto arbitrario, constitucionalmente vedado.

En resumen, tal y como hemos expuesto en las líneas anteriores, consideramos que el instituto jurídico del indulto, de acuerdo con las premisas del Estado de Derecho, debe responder a los siguientes criterios: (a) sujeción al principio de legalidad, (b) control judicial de los elementos reglados, (c) consecución de la Justicia material, (d) concesión acorde con los principios y valores constitucionales, (e) existencia indispensable de motivación.

18 LINDE PANIAgua, Enrique, “El indulto como acto de administración de Justicia y su judicialización. Problemas, límites y consecuencias», en Teoría y Realidad Constitucional, núm. 5, 2000, págs. 161-175. 


\section{Marco legal y naturaleza jurídica del indulto}

\subsection{Regulación vigente}

La principal mención constitucional del indulto se encuentra recogida en el art. 62.i de la Constitución Española de 1978 (CE) ubicado en elTítulo Il dedicado a la Corona. Se configura como una atribución formal del Rey (ejercer el derecho de gracia con arreglo a la ley, que no podrá autorizar indultos generales), con el refrendo del ministro responsable, de acuerdo con el art. 64 CE. Por su parte, el art. 102.3 CE establece que la prerrogativa real de gracia no será aplicable a los casos de responsabilidad criminal de los miembros del Gobierno. Y el art. 87.3 CE excluye de la iniciativa legislativa popular el derecho de gracia.

La STCJ reconoce que "la Constitución de 1978 es parca en sus referencias a este tipo de medida de gracia, únicamente mencionada en sus artículos 62 i, 87.3 y 102.3, aunque los dos últimos preceptos se limiten a consignar disposiciones meramente prohibitivas en torno al ejercicio de la misma». En esta línea, Pérez del Valle entiende que "por sí sólo, el texto del artículo 62.i CE no permite alcanzar otra conclusión que la que se refiere a la prohibición de los indultos generales» ${ }^{19}$.

$Y$ tan importante como la prohibición de los indultos generales es que el art. 62.i CE remite a la ley para la regulación y ejercicio del derecho de gracia ${ }^{20}$, puesto que como hemos comentado es uno de los requisitos para la adaptación de esta institución al Estado constitucional actual. La regulación legal vigente se encuentra, como ya hemos dicho, dispersa entre diversas normas procesales y sustantivas, aunque la más importante está contenida en la Ley provisional de 18 de junio de 1870 que establece reglas para el ejercicio de la gracia de indulto 21 , modificada parcialmente por la Ley $1 / 1988$, de 14 de enero.

19 Pérez del Valle, Carlos, "Amnistía, Constitución y justicia material", en Revista Española de Derecho Constitucional, núm. 61, enero-abril 2001, pág. 192.

20 El propio Anteproyecto de Constitución ya establecía que correspondía al Rey "ejercer el derecho de gracia con arreglo a la ley" (BOC de 5 de enero de 1978). La reserva de ley se ha mantenido a lo largo de la historia constitucional española. Para un análisis del indulto en la historia constitucional española vid. REQUEJo PAgés, Juan Luis, "Amnistía e indulto en el constitucionalismo español», en Revista Electrónica de Historia Constitucional, http://hc.rediris.es/dos/articulos/html/indulto.htm.

21 Para una descripción de los avatares históricos de esta ley, véase:LLORCA ORTEGA, José, La Ley de indulto (Comentarios, jurisprudencia, formularios y notas para sú reforma), Tirant Lo Blanch, Valencia, 1997, pág. 17. 
La Constitución habla de "derecho de gracia» (art. 62.i CE) o "prerrogativa de gracian (art. 87.3 y art. $102.3 \mathrm{CE}$ ), mientras que parte de la doctrina utiliza el más genérico de clemencia como un concepto que engloba diversas figuras entre las que podemos destacar el indulto particular, el indulto general y la amnistía. Su diferenciación se basa en tres aspectos: la titularidad, la motivación y las consecuencias que acarrea.

Como hemos destacado, el indulto particular es un acto del Gobierno que se exterioriza por un Real Decreto acordado en Consejo de Ministros, firmado por el Rey, con el refrendo del Ministro de Justicia. Las motivaciones, en lo que nos interesa ahora, son referidas al caso concreto. En cuanto a las consecuencias, el indulto particular remite la pena o parte de ella según que sea total o parcial, pero no elimina todas las demás consecuencias, como penas accesorias, responsabilidades civiles, antecedentes penales, etc. El indulto particular, a diferencia de la amnistía, no debe responder a criterios políticos, por lo que no puede calificarse estrictamente como un acto de dirección política.

El indulto general se encuentra actualmente prohibido por el art. 62.i CE. La motivación solía ser un acontecimiento relevante, por ejemplo la proclamación de don Juan Carlos de Borbón como Rey de Espa$\tilde{n} a^{22}$, y «lejos de concretarse en un caso determinado, afectan a una pluralidad de personas más o menos extensa, apriorísticamente designadas en función de las penas impuestas o por imponer, lo que posibilita la concesión anticipada de la gracia para quien no siendo aún reo o condenado ha sido procesado o simplemente encartado, lo que implica, procesalmente, el desplazamiento de la sentencia que remata el juicio por el sobreseimiento libre que elude el juicion. La pérdida del carácter excepcional, la falta de individualización ${ }^{23}$ y la invasión

22 Véase el Decreto 2940/1975, de 25 de noviembre. Sobre este decreto también se pueden consultar las siguientes resoluciones delTribunal Constitucional ATC $32 / 1981$ de 25 de marzo y STC 8/1981, de 30 de marzo.

23 La falta de individualización requeria que diversos órganos aplicaran la medida de gracia. En el fundamento jurídico segundo del ATC 32/1981 encontramos la explicación de esta situación: "La pretensión contenida en la demanda que da origen al presente recurso es la de que se conceda y aplique al recurrente el indulto general concedido por RD 2940/1975, de 25 de noviembre. La aplicación de las medidas generales de gracia, definidas en cada caso por los términos de la concesión y prohibidas hoy por norma constitucional expresa (art. 62.i de la Constitución), correspondía a los Tribunales ordinarios y no a esteTribunal, cuyo rasgo definitorio más característico es, precisamente, el de ser intérprete supremo de una 
manifiesta de funciones reservadas al Poder Judicial hicieron que los grupos parlamentarios rechazaran tal tipo de indultos en el proceso constituyente.

La amnistía, que no mencionada en la Constitución, ni el actual Código Penal, se diferencia de las figuras anteriores en que ésta extingue la pena y cualquiera de sus efectos, debido a que tal pena ha sido impuesta en aplicación de un delito que la legislación ya no considera como tal. Según elTC la amnistía no forma parte del derecho de gracia establecido en el art. 62.i CE, aunque ha considerado que podía estar constitucionalmente amparada por los efectos retroactivos de las disposiciones sancionadoras favorables de los derechos fundamentales (art. 9.3 CE) ${ }^{24}$. La amnistía se debe ejercer mediante Ley aprobada por las Cortes Generales, no pudiéndose por lo tanto acordarse por parte del Gobierno mediante Real Decreto-Ley (art. 86.1 CE) ni las propias Cortes realizar una delegación legislativa (art. 82.2 CE).

\subsection{Procedimiento}

Los trámites para solicitar y conceder, en su caso, el indulto particular se recogen en el capítulo III de la Ley de 1870.

La solicitud de indulto puede realizarse por el penado lo sus parientes o cualquier otra persona en su nombre sin necesidad de representación), por elTribunal sentenciador, por el Tribunal Supremo, por el Fiscal de cualquiera de ellos, y por el Gobierno «para la concesión de indultos que no hubiesen sido solicitados por los particulares, ni propuestos por los tribunales de justicia" (arts. 19, 20 y 21). De acuerdo con la legislación penitenciaria, el Juez de vigilancia penitenciaria puede tramitarlo a petición de la Junta de Tratamiento previa propuesta del Equipo de Técnicos, siempre que concurran condiciones de buena

Constitución que instaura un orden jurídico-político dentro del que carecen de sentido y resultan inadmisibles esas medidas generales de gracia. La falta de jurisdicción es, por tanto, manifiesta y puede fundamentar por sí sola la inadmisión del recurson. Pero no todos los supuestos contemplados en los indultos generales eran aplicados por los Tribunales. Un ejemplo de aplicación gubernativa del Decreto 2940/1975, de 25 de noviembre, lo encontramos en la Orden del Ministerio del Ejército de 26 de noviembre de 1975.

24 Vid., entre otras, SSTC 147/1986, 122/1984 y 63/1983. 
conducta del penado, desempeño de una actividad laboral normal y participación en las actividades de reeducación y reinserción (art. 206 del Reglamento Penitenciario aprobado por Real Decreto 190/1996, de 9 de febrero).

La Orden de 10 de septiembre de 1993, del Ministerio de Justicia, relativa a "instrucciones sobre la tramitación de solicitudes de indulto", después de admitir que en su tramitación y en las propuestas de concesión no le es de aplicación el procedimiento administrativo común en lo referente a plazos, considera que hay que aplicar el principio general de facilitación administrativa en el ejercicio de derechos y en la promoción de intereses legítimos del art. 35.i de la Ley 30/1992, de 26 de noviembre, de Régimen Jurídico de las Administraciones Públicas y del Procedimiento Administrativo Común. Por consiguiente, establece que la Subsecretaría de Justicia podrá ampliar la tramitación hasta seis meses, a partir de la recepción de los informes preceptivos, con la finalidad de que pueda asi completarse la observación de la conducta del penado.

Las solicitudes se dirigen al Ministerio de Justicia por medio del tribunal sentenciador, del jefe del establecimiento, del Subdelegado del gobierno o del Juez de vigilancia penitenciaria según los casos (art. 22). Las solicitudes se remitirán a informe del Tribunal sentenciador que debe remitirlo al Ministerio de Justicia (art. 23) ${ }^{25}$, con datos que se refieren a circunstancias personales y penales del penado, concluyendo el tribunal sentenciador su dictamen sobre "la justicia o conveniencia y forma de concesión de la gracia" (art. 25). En informes favorables al otorgamiento de indulto se ha destacado el escaso grado de malicia de los hechos, ínfimo daño o cuantía inferior del perjuicio causado, avanzada edad y buenos antecedentes, ausencia de grave peligro para la seguridad pública, juventud y corta edad, la incultura, etc.

La Circular de la Fiscalía del TS de 14 de abril de 1925 recuerda la importancia de que los tribunales sentenciadores aporten «cuantos documentos $y$ datos conduzcan al esclarecimiento de las circunstancias por las cuales proceda aconsejar la concesión o denegación del indulto». En este sentido el art. 26 indica que el Tribunal sentenciador remitirá junto con el informe, el historial penal, testimonio de la sen-

25 Más tarde, en el apartado IV, punto 4, del presente trabajo se comentan algunos de los problemas prácticos del informe del Tribunal sentenciador. 
tencia y «los demás documentos que considere necesarios para la justificación de los hechos".

También es necesario un segundo informe que evacuará el jefe del establecimiento si se trata de un interno o el Subdelegado del gobierno en otro caso. Después se oirá al Fiscal y a la parte ofendida si la hubiere (art. 24). El Decreto de 2 de abril de 1938, que declaró vigente la Ley de 1870, establece en su art. 3 que para la concesión de la gracia no se necesitará informe del Consejo de Estado, como requería el antiguo art. 28 de la Ley. La supresión de este informe supone la eliminación de un requisito que en cierto modo otorgaba más objetividad a la tramitación del indulto y la anulación de una opinión adicional. Esta supresión no tendría más trascendencia si no fuera porque la propia Administración reconoce en la Orden de 10 de septiembre de 1993 que "la experiencia adquirida en la tramitación de expedientes de indulto permite apreciar que la emisión en sentido favorable de los informes previstos en la Ley de 18 de junio de 1870 no resulta en todos los casos suficiente para la formación de criterios sobre la conveniencia o sobre la forma de la concesión de la gracia».

Con todos estos documentos se forma un expediente en el que se hacen constar las circunstancias que concurren en el caso y los informes evacuados. Corresponde a la Subsecretaría de Justicia la tramitación de los indultos de penas impuestas por la jurisdicción ordinaria.

Los expedientes de indulto solicitados por el Tribunal sentenciador se tramitarán de forma preferente (art. $4.3 \mathrm{CP}$ ), así como aquellos en los que haya motivos de "equidad" (ha sido frecuente la aplicación de este sistema en los últimos años) y también aquellos expedientes considerados de "especial urgencia o importancia" (art. 28 , en la nueva redacción dada por la Ley $1 / 1988$ ). Puede observarse que todos ellos son conceptos muy ambiguos, indeterminados y que permiten una amplísima discrecionalidad. El art. 6.1 del Real Decreto 1879/1994, de 16 de septiembre, establece que la tramitación de los expedientes de indulto debe hacerse en el plazo de un año, pudiendo entenderse desestimadas las solicitudes si no hay resolución expresa en dicho plazo.

El otorgamiento del indulto se hará en Real Decreto motivado previa deliberación del Consejo de Ministros a propuesta del de Justicia, que se publicará en el BOE (art. 4 del Decreto de 22 de abril 1938). Es frecuente que la motivación sea reproducir la frase escueta «teniendo en cuenta las circunstancias que concurren en los hechos" o "visto el expediente de indulto". Blanca Lozano considera que ello es insu- 
ficiente ${ }^{26}$. En nuestra opinión, no es sólo insuficiente sino que puede Ilegar a atentar contra el principio constitucional de interdicción de la arbitrariedad de los poderes públicos (art. 9.3 CE). Por ello a continuación pasamos a analizar los límites del ejercicio del derecho de gracia.

\subsection{Límites}

Como ya hemos destacado, uno de los principales aspectos que pueden convertir al indulto en un instituto jurídico adecuado en el marco del actual Estado de Derecho es la sujeción del derecho de gracia al principio de legalidad, lo que supone límites y controles. Los límites de las medidas de gracia provienen principalmente de dos fuentes. Por un lado, de la propia Constitución y, por otro, de la ley de 1870. Haremos especial referencia a los límites que se imponen al Gobierno, perspectiva desde la que analizamos el indulto en el presente trabajo, sin dejar por ello de citar los límites que se establecen al Legislador.

a) Límites al Legis/ador. El límite más importante que la Constitución establece al Legislador es la prohibición de elaborar una ley que establezca la figura del indulto general (art. 62.i CE). Las principales consecuencias que ello conlleva son: (a) la prohibición de indultos ex ante, es decir, antes de que se haya producido el juicio penal, (b) la exigencia de que se contemple una motivación personalizada, (c) que no pueda indultarse por motivos meramente políticos $y$ (d) que en la configuración juridica del indulto no se elimine el delito.También se prevé que no pueda existir iniciativa legislativa popular (art. 87.3 CE), lo que obliga a que la ley reguladora de tal figura impida la presentación de una iniciativa de los ciudadanos sobre el derecho de gracia 27 .

26 LOZANo, Blanca, "El indulto y la amnistía ante la Constitución», en Estudios sobre la Constitución española. Homenaje al profesor Eduardo García de Enterría, Civitas, Madrid, 1991, vol. Il, pág. 1049.

27 El art. 5.2 de la Ley Orgánica $3 / 1984$, de 26 de marzo, que regula la iniciativa legislativa popular indica que es causa de inadmisión de la proposición que tenga por objeto una materia excluida. El art. 127 del Reglamento del Congreso de los Diputados establece que la Mesa del Congreso examina las proposiciones de ley que provienen de la iniciativa popular "a efectos de verificar el cumplimiento de los requisitos legalmente establecidos». 
b) Límites al Gobierno. El principal es la reserva de ley (art. 62. i $\mathrm{CE})$, que como comentaremos debería ser ley orgánica, como mínimo en alguno de sus aspectos, con la consiguiente imposibilidad del Ejecutivo de regular la materia mediante Real Decreto-Ley o Decreto Legislativo. En segundo lugar destaca la prohibición de conceder el indulto al Presidente del Gobierno y a los demás miembros del Gobierno (art. 102.3 CE).

Además de los límites anteriores que podemos denominar explícitos, nos encontramos con límites constitucionales implícitos que se derivan de los principios y normas constitucionales y de una interpretación sistemática del texto constitucional para que, como hemos afirmado, esta figura tenga un encuadre adecuado en la estructura del Estado de Derecho.

a) Dirigidos al Legislador. El límite implícito más importante que la Constitución establece respecto al Legislador es la consideración del indulto como una figura de carácter excepcional, que no puede convertirse en un nuevo recurso o en una nueva instancia. El carácter excepcional es requisito necesario, como hemos afirmado, para que no se menoscaben las competencias del Poder Judicial.

b) Dirigidos al Gobierno. Si el indulto tiene un carácter excepcional, el ejercicio de éste debe ser igualmente restrictivo ( $y$ aunque sea una reiteración, excepcional). El ordenamiento jurídico contempla diversas figuras que tienden a la consecución de la Justicia material (remisión condicional de la pena, libertad condicional...) con lo cual el indulto debe utilizarse cuando los otros instrumentos no han dado resultado o no se pueden utilizar. Como dice Blanca Lozano, "la admisión de la clemencia individual no implica en ningún modo una habilitación sin límites al Ejecutivo para que utilice este delicado instrumento jurídico. El indulto debe adaptarse a las exigencias del sistema constitucional, lo que conlleva, por un lado, la limitación de su ejercicio, $y$, por otro, la racionalización del procedimiento para su concesión ${ }^{28}$. Esta autora defiende su carácter ex-

28 LozANo, Blanca, "El indulto y la amnistía ante la Constitución”, en Estudios sobre la Constitución española. Homenaje al profesor Eduardo García de Enterría, Civitas, Madrid, 1991, vol. II, pág. 1045. 
cepcional y considera alarmante su creciente utilización en España, aunque inferior a Italia, entendiendo que no puede concebirse como una nueva instancia judicial, en la que se actúa sin garantías.

Como hemos argumentado anteriormente, la Constitución exige que los actos de los poderes públicos estén motivados, y en consecuencia la concesión de un indulto debe razonarse. A lo que es necesario añadir que debe razonarse individualmente, dada la naturaleza particular del indulto. En este sentido Enrique Linde expresa que el indulto particular no puede ser utilizado "masivamente» de tal manera que se convierta en un indulto general ${ }^{29}$. Respecto a este último aspecto hemos de destacar que la prohibición de indultos generales no hace referencia a un aspecto cuantitativo sino al hecho de que para cada caso haya su propia motivación, y que se refieran a un condenado en particular. En este sentido, Blanca Lozano entiende que la finalidad de justicia reparadora que se pretende podría ser una mera farsa y dar lugar a una actuación inconstitucional si diversos decretos singulares responden a una misma motivación política ${ }^{30}$. Linde Paniagua, también destaca que la concesión del indulto «no puede utilizarse como reforma, por la vía de hecho, de leyes consideradas injustas con carácter indefinido" puesto que pervertiría las funciones que constitucionalmente se establecen para el Gobierno y para las Cortes Generales.

Finalmente, respecto a los criterios que deben presidir la concesión del indulto, debemos hacer especial mención al principio de proporcionalidad, reduciendo la pena en los casos en que una aplicación estricta de la ley comporte un castigo considerado excesivo y el de reinserción social, considerando que la aplicación de la ley penal no tiene sentido desde este punto de vista puesto que la persona ha corregido su conducta y está perfectamente reinsertada socialmente. El Tribunal Constitucional en la STC 35/1994, de 31 de enero [RTC 1994/35] ha hecho expresa referencia a estos criterios, establecidos en el art. 25 CE: "Otros mecanismos tienden a paliar las nocivas conse-

29 Linde Paniagua, Enrique, "La clemencia (amnistía e indulto) a la luz de la jurisprudencia de los tribunales Supremo y Constitucional y del Código Penal de 1995", en Boletín de Información del Ministerio de Justicia, núm. 1823, 15 de junio de 1998, pág. 15.

30 LOZANO, Blanca, "El indulto y la amnistía ante la Constitución», en Estudios sobre la Constitución española. Homenaje al profesor Eduardo García de Enterría, Civitas, Madrid, 1991, vol. II, pág. 1047. 
cuencias personales, familiares, laborales o de otra índole que de ese indebido retraso pueden derivarse para el condenado, en relación con la orientación que el art. 25.2 CE establece para las penas privativas de libertad, orientación que, más allá de la finalidad de la pena, trata de facilitar y favorecer al penado que pierde su libertad una efectiva reinserción en la sociedad y una adecuada rehabilitación. En este marco pueden situarse, por ejemplo, el indulto (...)».

Por otro lado, hay que destacar que la actual Ley del indulto nació para limitar la potestad de la Corona de conceder indultos y a tal efecto establecer ciertos límites al ejercicio del derecho de gracia. Debemos recordar, sin embargo, que muchos de los límites legales han quedado hoy superados por los límites constitucionales acabados de comentar. El destinatario de los límites legales no es otro que el órgano encargado de ejecutar la ley, es decir, el Gobierno. En este sentido se configuran como los elementos reglados de este acto parcialmente discrecional, es decir, los límites son plenamente controlables por el Poder judicial.

Podemos clasificar los límites legales impuestos al Gobierno en las siguientes categorias:

a) De procedimiento. La propia existencia de un procedimiento legalmente establecido $y$ la necesidad de adecuarse a éste (art. 1 Ley de indulto) es, sin lugar a dudas, el principal límite del Gobierno en el ejercicio del derecho de gracia. A lo largo de la tramitación, la petición de informes al Tribunal sentenciador $y$ al jefe de la prisión si está recluido o al Subdelegado del Gobierno en caso contrario (art. 23-25 Ley de indultol y la audiencia al Ministerio Fiscal y a la víctima (art. 28 Ley de indulto) se convierten en los principales requisitos de este procedimiento.

b) En su concesión. Hemos expuesto anteriormente que el hecho de indultar a una persona o no hacerlo es una decisión discrecional del Gobierno. No obstante, una vez se ha decidido indultar a un penado, el Gobierno no tiene las manos libres para disponer que su decisión tenga cualquier alcance. Su decisión es irrevocable (art. 18 Ley de indulto). Además, es necesario concretar la pena principal sobre la que recae la gracia (art. 5 Ley de indulto). Respecto de la pena en concreto se establecen dos límites. El primero es la prohibición de indultar penas ya cumplidas (art. 4 Ley de indulto) y el segundo la imposibilidad de que se conceda indulto total con informe desfavorable del Tribunal senten- 
ciador (art. 11 Ley de indulto). Respecto al alcance, se excluye la indemnización civil (art. 6 Ley de indulto) y de las costas procesales (art. 9 Ley de indulto). Finalmente, la decisión del Gobierno no puede perjudicar los derechos de terceras personas (art. 15 Ley de indulto).

c) En su forma. El art. 30 de la Ley de indulto requiere que la concesión de indultos se exteriorice mediante Real Decreto publicado en el Boletín Oficial del Estado. Esta redacción procede de la Ley $1 / 1988$, de 14 de enero que suprimió la anterior mención "Decreto motivado". A nuestro entender este cambio no debería tener ninguna trascendencia práctica en el razonamiento de la concesión de indultos puesto que la motivación de tales actos es una exigencia constitucional derivada de la prohibición de la arbitrariedad de los poderes públicos.

\subsection{Controles}

Como ya hemos insinuado anteriormente, la concesión del indulto ha de ser compatible con el control de los elementos reglados establecidos por la ley. El indulto, como todo acto del Gobierno, está sometido a los controles previstos para los actos del Poder Ejecutivo. El control parlamentario es algo innegable en nuestro sistema constitucional ${ }^{31}$, que sólo debe tener los límites que la propia Constitución establece en relación a la intimidad de las personas y demás derechos fundamentales que correspondan al indultado, según el caso.

El control judicial del indulto es también incuestionable, ya que es una exigencia del Estado de derecho. Como hemos anticipado, aunque el indulto es discrecional en su otorgamiento contiene elementos reglados que permiten y exigen el control jurisdiccional. Otro aspecto son las dificultades prácticas de dicho control, por la poca motivación, la inexistencia de regulación de un recurso por el interesado si se incumplen los requisitos legales, o un control judicial que no tiene doble instancia. Un ejemplo concreto de esas dificultades

31 Cfr. LÓPEZ Aguilar, Juan Fernando, «Una reflexión a propósito del control parlamentario del ejercicio del derecho de gracian, en Revista de las Cortes Generales, núm. 37, 1996, págs. 329-342. 
prácticas es la ausencia de notificación por el Gobierno en el supuesto de la denegación del indulto.

No obstante estas dificultades prácticas, el Tribunal Constitucional ha tenido ocasión de declarar que: «El indulto, en cuanto figura del derecho de gracia, corresponde decidirlo al Poder Ejecutivo concediéndolo el Rey, sin que esas decisiones sean fiscalizables sustancialmente por parte de los órganos jurisdiccionales, incluyendo este Tribunal Constitucional" (ATC 360/1990, F.5). Es importante destacar el adverbio "sustancialmente" puesto que reafirma, por un lado, nuestra consideración de que en esencia es un acto discrecional, pero, por el otro, que el resto de componentes del acto, al ser reglados, no deben impedir un control jurisdiccional. A ello cabe añadir que dicha afirmación tan contundente del Tribunal Constitucional podría ser debida a la opinión mantenida por el Ministerio Fiscal en el caso concreto, que encontramos recogida en los antecedentes de hecho: "Lo que deberia haberse impugnado era el Acuerdo del Consejo de Ministros de 1 de junio de 1990 que denegó la petición de indulto, posteriormente, no obstante, concedido" (ATC 360/1990, Antecedente de hecho 6). Esta afirmación del Ministerio Público puede llevar a pensar que un Decreto denegando un indulto se puede impugnar en todo caso, como si existiera un derecho al indulto, cuando lo más correcto es, como ya hemos afirmado, separar aquellos elementos reglados que sí que se pueden impugnar, de la consideración de si se indulta o no, que no es fiscalizable por los Tribunales de Justicia. El Tribunal Supremo claramente los ha diferenciado al destacar que: «EI otorgamiento del indulto constituye (...) una consecuencia de la prerrogativa real de gracia, de suerte que su denegación constituye un acto no sujeto al Derecho Administrativo (...), la revisión de la denegación del indulto solicitado recae fuera del ámbito de aquella jurisdicción, excepto en el aspecto puramente procedimental de cumplimiento de los trámites establecidos para su adopción, que pueden ser fiscalizados, en su aspecto meramente administrativo por la Jurisdicción" (Auto delTS de 31 de enero de 2000 [RJ 20001506(). En este línea, el Tribunal Constitucional también ha afirmado que el «ejercicio del derecho de gracia (...) dispone de un amplio margen de discrecionalidad, como demuestra el hecho de que posteriormente sí se concediera el indulto solicitado por nueva decisión del Consejo de Ministros" (ATC 360/1990, F. 4).

Esta doctrina parecía asentada, en coherencia con la actual Ley 29/1998, de 13 de julio, reguladora de la Jurisdicción ContenciosoAdministrativa, que se reafirma en la inexistencia de "actos políticos" no hiscalizables, como consecuencia del espíritu de la norma consti- 
tucional32.Y al principio del "caso Liaño" encontramos una ratificación de esta postura expresada en el Al, que recordó esta idea en los siguientes términos: "Como señala la doctrina y la jurisprudencia, aun cuando nos encontramos ante un poder discrecional que administra el Poder Ejecutivo, por amplia que sea cualquier discrecionalidad, siempre será un quid alliud respecto de la ley, como cualquier otro producto administrativo, y estará por ello "sometida plenamente" a la Ley $y$ al Derecho. El control judicial de la discrecionalidad es siempre un control de los elementos reglados con que la atribución legal de la potestad correspondiente ha sido atribuidan. En el Al se recuerda que la prerrogativa de gracia está sujeta a la ley ${ }^{33}$ y que su aplicación corresponde al Tribunal sentenciador ${ }^{34}$, concluyendo que: "Los órga-

32 En este sentido, la exposición de motivos de la actual Ley 29/1998, de 13 de julio, reguladora de la Jurisdicción Contencioso-Administrativa remarca: «La Ley no recoge ya, entre estas exclusiones, la relativa a los llamados actos políticos del Gobierno, a que se refería la Ley de 1956» (...). "La Ley parte del principio de sometimiento pleno de los poderes públicos al ordenamiento jurídico, verdadera cláusula regia del Estado de Derecho. Semejante principio es incompatible con el reconocimiento de cualquier categoría genérica de actos de autoridad -llámense actos políticos, de Gobierno, o de dirección política- excluida "per se" del control jurisdiccional. Sería ciertamente un contrasentido que una Ley que pretende adecuar el régimen legal de la Jurisdicción Contencioso-Administrativa a la letra y al espíritu de la Constitución, llevase a cabo una introducción de toda una esfera de acción gubernamental inmune al derecho. En realidad, el propio concepto de "acto político" se halla hoy en franca retirada en el Derecho público europeo. Los intentos encaminados a mantenerlo, ya sea delimitando genéricamente un ámbito en la actuación del poder ejecutivo regido sólo por el Derecho Constitucional, y exento del control de la Jurisdicción Contencioso-Administrativa, ya sea estableciendo una lista de supuestos excluidos del control judicial, resultan inadmisibles en un Estado de Derecho.

Por el contrario, y por si alguna duda pudiera caber al respecto, la Ley señala -en términos positivos - una serie de aspectos sobre los que en todo caso siempre será posible el control judicial, por amplia que sea la discrecionalidad de la resolución gubernamental: los derechos fundamentales, los elementos reglados del acto y la determinación de las indemnizaciones procedentes".

33 "En todo caso se trata de una prerrogativa sujeta a la ley y corresponde al Poder Judicial velar por la efectividad de esa sujeción, precisamente porque comporta cierta derogación del principio de generalidad de la ley penal y de los de independencia y exclusividad de la jurisdicción".

34 "Cualquiera que sea la naturaleza de un Real Decreto de Indulto, la aplicación de la gracia corresponderá siempre al Tribunal sentenciador y así lo establece, de manera rotunda, el artículo 31 de la Ley de Indulto de 18 de junio de 1870 , reformada por Ley de 14 de enero de 1988 que refuerza la competencia de forma inequívoca, encomendándole esta facultad, de manera directa e "indispensable". Esta capacidad se reitera en otros diversos preceptos de dicha ley, como el artículo 17, que dispone que el Tribunal sentenciador no dará cumplimiento a ninguna 
nos competentes para otorgar el indulto y para aplicarlo, son distintos, evitándose de esta manera la incontrolada disposición de esta facultad por parte del Poder Ejecutivo. Nadie discute que el Gobierno tiene un papel relevante, decisorio y exclusivo en el otorgamiento de la gracia de indulto, pero condicionado por la legalidad y controlado por el Poder Judicial a través del órgano sentenciador".

Sin embargo, posteriormente la STCJ supuso una matización de esta doctrina, cuanto no un quebranto y un paso atrás en la concepción del control de los elementos reglados de los actos discrecionales $y$ en lo referente a la discrecionalidad en la concesión del indulto. Observamos tres grandes diferencias respecto a la doctrina de la Sala Segunda del Tribunal Supremo expresada en el Al. En primer lugar, se menosprecia y deslegitima el control jurisdiccional del Tribunal sentenciador al considerar que la aplicación del indulto por éste es una cuestión de "prestigio" más que de "control de legalidad" y de aplicación estricta de la misma. La STCJ llega a argumentar que «el Preámbulo del Proyecto de la Ley de Indulto presentado por el Ministerio de Gracia y Justicia a las Cortes Constituyentes -Diario de Sesiones, 17 de diciembre de 1869, Apéndice VIII - restringe profundamente el sentido del artículo 31 al señalar que ues altamente necesario que el indulto, aun en los casos en que más justificado sea, no quebrante el prestigio de que deben gozar siempre losTribunales, sin el cual se haría imposible su misión social. Por esto, al Tribunal sentenciador habrá de encargarse la aplicación de la gracia, a fin de que el delincuente reciba de la misma mano que le impuso la pena el beneficio del perdón que se le otorgue». Esta identidad de mano aspira al mantenimiento del prestigio de los Tribunales más que a un control de legalidad" (STCJ, F. 3). En segundo lugar, «degrada» el objeto del control al afirmar que: "Ante todo, es de advertir que no nos encontramos en el supuesto del artículo $6 .^{\circ}$ de la Ley Orgánica del Poder Judicial que señala que "los Jueces y Tribunales no aplicarán los reglamentos o cualquier otra disposición contrarios a la Constitución, a la ley o al principio de jerarquía normativa". Este precepto se proyecta sobre normas y no sobre actos. EI RD de indulto ha de ser encuadrado dentro de esta última categoría, ya que se agota con su ejecución y no es susceptible de una pluralidad indefinida de aplicaciones. Aún cabe añadir que el indulto es un acto declarativo de derechos y por ello dotado de una especial virtualidad jurídica, con lo que se dota mayor relevancia a la 
necesidad de que el control de la legalidad del acto que los otorga se someta a una tramitación en la que sean oídos, tanto la persona a cuyo favor deriven esos derechos, como el autor del acton (STCJ, F. 3). Y en tercer lugar, agrava los requisitos y criterios necesarios para llevar a cabo el control jurisdiccional al exigir una «manifiesta vulneración de la legalidad", como claramente queda patente en las afirmaciones siguientes: «Pese a todo ello es innegable que, atendiendo tanto al principio de legalidad como al de oficialidad característico de la jurisdicción penal, constituye una exigencia derivada de la misma función atribuida alTribunal de esa jurisdicción con relación a la ejecución de la sentencia - artículo $\mathbf{1 1 7 . 3}$ de la Constitución - en la que incide el indulto, el admitir que pueda ejercer un control de la aplicación del mismo en determinados y concretos supuestos, en los que se haya producido una manifiesta vulneración de la legalidad" (STCJ, F. 4).

En el apartado siguiente, dedicado al análisis del "caso Liaño", tendremos ocasión de observar más detenidamente la larga historia de avatares tensos y en ocasiones desconcertantes a que ha dado lugar el mencionado caso, cuyo último exponente es la STCJ. Por ello se hace recomendable y urgente la reforma legal o la aprobación de una nueva ley del indulto, que clarifique y ordene este instituto jurídico.

\section{EL "CASO LIAÑO»}

\section{Desarrollo del caso}

\subsection{Antecedentes. Del "caso Sogecable» al expediente de indulto}

El 24 de febrero de 1997 Jaime Campmany presenta una denuncia por presunto uso indebido de los depósitos de los abonados a la plataforma de televisión digital "Canal Satélite Digital» por parte de dos empresas (Sogecable y Canal Plus) en las que tiene inversiones el Grupo PRISA. La instrucción de este caso correspondió al entonces Juez de Instrucción del Juzgado de Instrucción Central núm. 1, Javier Gómez de Liaño. La instrucción fue muy polémica, particularmente en lo referente al secreto de sumario y a la prohibición de salida del territorio español de alguno de los acusados (especialmente relevante fue la prohibición a Jesús de Polanco, que debía ser investido doctor honoris causa por la Universidad americana de Brown). La Audiencia Nacional rectificó continuamente las decisiones de Gómez de Liaño y el Consejo General del Poder Judicial incoó expediente disciplinario por la desconsideración de Gómez de Liaño a los magistrados de la Audiencia que habían revocado sus autos. 
Los acusados recusaron a Gómez de Liaño. Este hecho agravó si cabe más la polémica, puesto que el juez encargado de resolverla, Baltasar Garzón, se abstuvo en el incidente de recusación declarando tener conocimiento extraprocesal de reuniones entre Gómez de Liaño $y$ el denunciante, Jaime Campmany, que confabulaban (junto con determinados fiscales, jueces y periodistas) para «acabar con el sistema políticon. Estas declaraciones iniciaron la Causa Especial 2790/1997 que fue archivada por auto el día 21 de octubre de 1997. La Sala de Gobierno de la Audiencia Nacional aceptó la abstención de Baltasar Garzón.

El juez Ismael Moreno se encarga entonces de la instrucción del "caso Sogecable». El 4 de noviembre de 1997, la Audiencia Nacional archiva el caso al considerar que los acusados no han cometido los delitos de apropiación indebida y estafa, remitiendo el caso al juzgado de instrucción ordinario, al entender que el mismo ya no es competencia de la Audiencia Nacional.

Los acusados formularon querella por prevaricación judicial contra el citado Magistrado Javier Gómez de Liaño, que se resolvió por la sentencia de 15 de noviembre de 1999 (SC), en la que se condenó a éste por un delito continuado de prevaricación, a 18 meses de multa a razón de 1.000 pesetas diarias y a la inhabilitación especial para empleo o cargo público por el tiempo de 15 años, «con la pérdida del cargo que ostenta y de los honores que le son anejos, así como con la incapacidad para obtener durante el tiempo de la condena cualquier empleo o cargo con funciones jurisdiccionales o de gobierno dentro del Poder Judicial o funciones jurisdiccionales fuera del mismo". La sentencia, en el análisis de uno de los autos que dictó el magistrado, llegó a decir que "la contradicción con la norma es tan clara que resulta, por ello, manifiesta, llamativa e inclusive grosera". A esta sentencia formuló voto particular el Magistrado José Manuel Martínez-Pereda Rodríguez el que, si bien destaca el «empecinamiento del Instructor" no considera que con esta actitud se llegue al extremo de dictar resoluciones injustas a sabiendas, considerando que la mera ilegalidad de las resoluciones no conduce inexorablemente a la existencia de delito.

Dos días después, el 17 de noviembre de 1999, los políticos de Izquierda Unida Julio Anguita y Pablo Castellanos iniciaron una campaña de recogida de fondos para sufragar los gastos del juicio y de la multa impuesta y a este fin abrieron una cuenta en una entidad bancaria. La prensa se hizo eco de todo el proceso. Las opiniones, lejos de estar encontradas, mostraban como trasfondo una guerra mediáti- 
ca palpable. El Grupo PRISA es editor del diario EI País, mientras que Jaime Campmany es miembro de la Asociación de Escritores y Periodistas Independientes (AEPI) ${ }^{35}$, también conocida con el sobrenombre de "Sindicato del crimen»" ${ }^{36}$, que reúne a personajes en torno a las publicaciones $A B C$, El Mundo y Época. En $A B C$ Jaime Campmany destacó que uel magistrado Gómez de Liaño fue condenado por dos jueces visiblemente ligados al Partido Socialista" y «el tercer miembro del Tribunal (...) no pudo hacer otra cosa que dejar su opinión contraria a la condena en un voto particular que es una pieza ejemplar de argumentación jurídica y de criterio equitativo»" ${ }^{37}$.

En este contexto, el propio Gómez de Liaño pide el indulto e incluso intenta la suspensión de la aplicación de la pena hasta que se pronunciase el Gobierno o el Tribunal Constitucional, al que acudió en amparo $^{38}$. El Fiscal emitió un informe favorable a la concesión del indulto, pero el del Tribunal sentenciador fue negativo (ITS). La Sala Segunda del Tribunal Supremo, recogía la idea de que la pena de inhabilitación especial impuesta a Liaño ya había sido ejecutada y por tanto era imposible reintegrar a Liaño en la carrera judicial durante los 15 años que duraba el tiempo de la condena (interpretando el art. 4 de la ley del indulto en el sentido de que no se puede indultar una pena ya ejecutada). Para el Tribunal Supremo, la pena de inhabilitación comporta, a) privación definitiva del cargo (expulsión de la carrera judicial) - esto no se puede indultar - ; b) incapacidad para ejercer este cargo durante el tiempo de la condena - esto sí que se puede indultar-39.

35 El dia 13 de agosto de 1994, un grupo de periodistas constituyeron la autodenominada Asociación de Escritores y Periodistas Independientes (AEPI) como una «asociación independiente en defensa de la libertad de expresión». EI consejo fundador estaba integrado por Luis María Anson, José Luis Balbín, Antonio Burgos, Camilo José Cela, Julio Cerón, Antonio Gala, José María García, Antonio Garcia-Trevijano, Teodoro González Ballesteros, José Luis Gutiérrez, Antonio Herrero, Federico Jiménez Losantos, Julián Lago, Manuel Martín Ferrand, José Luis Martín Prieto, Luis del Olmo, Raúl del Pozo, Pedro J.Ramírez, Pablo Sebastián y Francisco Umbral.

36 Recibió este nombre por el título de un soneto que compuso Francisco Umbral, que decia: «Los Dalton están llorando / al pie de una rotativa / porque Jesús de Polanco / sólo publica mentiras».

37 Jaime CAMPMANY, "El indulto», $A B C$, sábado 2 de diciembre de 2000.

38 Sus abogados, Jorge Trías y María Dolores Márquez de Prado, presentaron una demanda de 115 folios el 28 de octubre de 1999 en la que se denunciaban ocho vulneraciones de derechos fundamentales.

39 Cfr. Informe del Tribunal Supremo (Sala Segunda) de 14 de junio de 2000. 
Desde El Mundo, Antonio García Pelegrín, en un artículo de opinión titulado "Liaño: juicio injusto, indulto necesario" ${ }^{40}$, arremete contra los magistrados que han condenado a Liaño destacando sus relaciones con el PSOE, a su vez relacionado con el Grupo PRISA y su presiden. te, Jesús de Polanco.

\subsection{El Real Decreto de indulto}

El Consejo de Ministros concede el 1 de diciembre de 2000 un total de 1.443 indultos (a insumisos ${ }^{41}$, al ex alcalde de Burgos ${ }^{42}$, a encausados por el "caso Filesa" 43, a "Tani»" 44 , a Liaño), la primera medida de gracia masiva desde la aprobación de la Constitución, que se van publicando sucesivamente. Los motivos que aduce el Ministro de Justicia son: el jubileo, la petición del Papa; el vigésimo segundo aniversario de la Constitución; el fin del milenio, y los veinticinco años de la Monarquía. Hemos de tener en cuenta que no se trata de un indulto general, lo cual hubiera sucedido si con una misma motivación se indultaria a un conjunto de personas sin individualizar su caso. Por el contrario, estamos ante un conjunto de indultos particulares - único permitido por la CE - pero muy numeroso y en el que cabría criticar la mencionada motivación aducida por el Ministro de Justicia. De los indultos concedidos, el de Liaño salta desde el principio a la primera línea del debate jurídico, político y mediático. Además se convierte en un pulso entre el Gobierno y el Tribunal Supremo, como tendremos ocasión de observar ${ }^{45}$.

40 Antonio Garcia Pelegrín, "Liaño: juicio injusto, indulto necesario», El Mundo, 30 de marzo de 2000.

41 La medida beneficia a 460 insumisos. A treinta insumisos anteriores a 1995 se les condona la pena y a los posteriores se les reduce la inhabilitación absoluta de diez a cuatro años de inhabilitación especial.

42 Condenado a 12 años de inhabilitación por prevaricación, podrá volver a ser elegido para ocupar un cargo público. dicional.

43 Con el indulto, los tres encausados pasarán a la situación de libertad con-

44 Condenada a 14 años y 8 meses de prisión por matar a su marido, recupera la libertad condicional por haber cumplido las tres cuartas partes de la pena.

45 Reproducimos a continuación el texto del Real Decreto 2392/2000, de 1 de diciembre, de indulto a Liaño (DI) y publicado el 21 de diciembre de 2000 en el BOE núm. 305: "Visto el expediente de indulto de don Francisco Javier Gómez de Liaño y Botella, con los informes del Ministerio Fiscal y del Tribunal sentenciador, condenado por la Sala Segunda Sala de to Penal del Tribunal Supremo, en sen- 
Joan J. Queralt, desde El País, con el título «El indulto de la prevaricación judicial", advierte del conflicto institucional que el indulto puede plantear, critica la falta de motivación y llama la atención sobre qué es indultable y qué no. Después de afirmar que el juez fue condenado a 15 años de inhabilitación y multa considera que la primera pena comporta dos fases, la separación de la carrera judicial y la imposibilidad de presentarse a unas oposiciones o ser nombrado juez durante 15 años. De estos dos elementos, el primero ya fue ejecutado en octubre de 2000 por el CGPJ, separándolo de la carrera judicial. Esta parte de la pena ya está agotada y no se puede indultar. Considera que parece que el Gobierno confunde inhabilitación con suspensión, y que aquel «no sólo se ha inventado una nueva pena, sino que nombra sin habilitación alguna juez a quien no puede serlo, y también se inventa al margen de la Ley un modo de restricción profesional: la imposibilidad de acceder a la Audiencia Nacional durante 25 años» ${ }^{46}$. Gonzalo Quintero Olivares escribe en La Vanguardia "El derecho de gracia", en el que defiende la tesis de que el Gobierno ha pretendido rehabilitar al juez Gómez de Liaño y que esto no es de su competencia. Sostiene que en el presente caso estamos ante «el indulto de una pena principal de inhabilitación con la decisión añadida de dejar sin efecto un acuerdo del pleno del Consejo General del Poder Judicial en virtud del cual aquel magistrado era apartado definitivamente de la carrera judicial». Se ha producido pues una invasión en las competencias del CGPJ, único que constitucionalmente puede separar o reincorporar a un juez ${ }^{47}$. Francesc de Carreras, en un artículo publicado en El Periódico de Cataluña, titulado "Por qué se ha indultado a Liaño", expone

tencia de fecha 15 de octubre de 1999, como autor de un delito continuado de prevaricación, a la pena de multa de dieciocho meses, a razón de 1.000 pesetas diarias, e inhabilitación especial de empleo o cargo público por el tiempo de 15 años, por hechos cometidos en el año 1997, a propuesta del Ministerio de Justicia y previa deliberación del Consejo de Ministros en su reunión del día 1 de diciembre de 2000 ,

Vengo en indultar a don Francisco Javier Gómez de Liaño y Botella la pena de inhabilitación especial, con todas sus consecuencias, lo que supone el reintegro a la Carrera Judicial, manteniéndose, sin embargo, la incapacidad para desempeñar cargo en la Audiencia Nacional o en cualquier juzgado de la misma, durante el plazo de veinticinco años desde la publicación del presente Real Decreto, a condición de que no vuelva a cometer delito doloso durante el tiempo de normal cumplimiento de la condena".

46 Joan J. QUERALT, "El indulto de la prevaricación judicial», El País, 5 de diciembre de 2000.

47 Gonzalo QuinTERo Olivares, «El Derecho de gracia», La Vanguardia, 21 de diciembre de 2000 . 
la falta de motivación de la decisión gubernamental de indultar al juez Gómez de Liaño. Las motivaciones, afirma, deben ser "convincentes, fundadas en justificaciones legales y constitucionales que impidan la arbitrariedad y permitan el control de los decretos de indulto por parte de los tribunales de justicia". Al ser general que los Gobiernos concedan indultos sin ningún tipo de motivación se hace imposible el control de la arbitrariedad de tales decisiones. En el presente caso, entiende que el Gobierno decide cambiar la ejecución de una sentencia judicial condenatoria por prevaricación sin dar los motivos de su decisión. Con ello se vulnera el principio de la separación de poderes y se actúa de forma contradictoria con el Estado democrático de Derecho. Propugna el autor la necesidad de elaborar una nueva ley del indulto que supere la vetusta de 1870 y que ponga énfasis en la motivación de los decretos de indulto. Sostiene además que el decreto de indulto desborda las competencias del Gobierno e invade competencias del CGPJ al incapacitarlo para desempeñar cargos en la Audiencia Nacional durante 25 años $^{48}$.

En $A B C$, Jaime Campmany considera, sin embargo, que «pocas veces un indulto habrá venido, no a mitigar o cancelar una pena, sino a reparar una injusticia tan evidente y tan tercamente elaborada como este que ahora concede el Gobierno al juez Javier Gómez de Liaño " 49. Este diario, en su editorial del día 2 de diciembre de 2000, titulado "Gracia y Justicia", destaca que "el amplio espectro social de los beneficiarios del indulto impide su interpretación en clave política". El Periódico de Cataluña, en el editorial "Indulto con injusticias", del mismo día, sostiene que el indulto a Liaño es diferente del resto, ya que «rompe la tradición, la razonable tradición, de que los jueces condenados por triple prevaricación, no puedan volver a juzgar a nadie». Resalta el trasfondo político de la medida, y considera que tampoco debería haberse aplicado el indulto a los casos Filesa o Burgos, ya que es poco elegante que los políticos se indulten entre sí, para concluir que "se tendría que haber respetado la necesidad social de que los jueces y los políticos cumplan siempre los castigos merecidos". Por su parte, desde El Mundo se buscaron todos los argumentos posibles

48 Francesc DE CARRERAS, "Por qué se ha indultado a Liaño", El Periódico de Cataluña, 10 de enero de 2001. En un sentido parecido, considerando que no se saben las razones del indulto y que se ha vulnerado el principio de separación de poderes en el artículo publicado por los diputados del grupo socialista Juan Fernando LOPEZ AgUILAR y Diego LóPEZ GARRIDo, "El indulto prodigioso», El País, 13 de diciembre de 2000.

49 Jaime CAMPMANY, "El indulto", $A B C$, sábado 2 de diciembre de 2000. 
para argüir que la pena por prevaricación no se había cumplido, defendiendo que Gómez de Liaño no había perdido la condición de funcionario dado que la LOPJ no incluye la inhabilitación como motivo de separación de la carrera judicial $y$, que, en consecuencia, se podía indultar. Las únicas penas que no pueden ser indultadas serían aquellas definitivamente cumplidas y este no es el caso de la inhabilitación, que es reversible, según se establece en el art. 6 de la ley del indulto. El gran defensor de esta postura fue Enrique Gimbernat ${ }^{50}$, quien fue respondido por gran parte de la doctrina ${ }^{51}$. Cabe destacar, sin embargo, que ninguna de las resoluciones dictadas hasta el momento ponen en duda que Gómez de Liaño haya perdido la condición de Magistrado.

El Mundo, en su editorial del dia 2 de diciembre de 2000 titulado "Un indulto discutiblemente amplio hace justicia a Liaño", destaca que el Gobierno ha actuado correctamente ante la "inaudita pena" de 15 años de inhabilitación» al juez Gómez de Liaño, aprovechando para criticar el indulto a políticos del caso Filesa, de la construcción de Burgos o los fondos del PER, afirmando: "Siempre hemos sostenido que los delitos cometidos por responsables políticos deben merecer un tratamiento más riguroso y ejemplar». Por su parte, desde El País, Javier Pradera opina que el número tan elevado de indultos tiene como intención "meter dentro de sus filas» el perdón a Gómez de Liaño y en este sentido «la teatral atribución a María Teresa Moreno, Tani, y a 460 insumisos del papel de figurantes en el coro de la tragedia es una simple artimaña gubernamental orientada a ganarse las simpatías de las mujeres maltratadas $y$ de los movimientos de desobediencia civil. La gracia concedida a los condenados de Filesa es otra astucia no menos burda, dirigida esta vez a tapar la boca a los socialistas ${ }^{52}$. El propio diario, en su editorial del día 2 de diciembre de 2000 titulado "Uno de los suyos", declara que restituir en la carrera judicial a Gómez de Liaño es un insulto al Tribunal Supremo, al sentido común y al derecho de los ciudadanos a un juez imparcial. En el editorial del 10 de

50 Enrique Gimbernat, "Sobre el indulto de Gómez de Liaño», El Mundo, 8 de diciembre de 2000, y también "Significado de la "pena cumplida" en la ley de indulton, El Mundo, 13 de diciembre de 2000.

51 Cfr. José Miguel Zugaldia Espinar, "Las curiosas teorias del profesor Gimbernat Ordeig", El País, 14 de diciembre de 2000; María Inmaculada Ramos TAPIA, «El alcance del indulto a Liaño», EI País, 15 de diciembre de 2000, o Gonzalo Quintero Olivares, "El derecho de gracia», La Vanguardia, 21 de diciembre de 2000.

52 Javier Pradera, "Patente de corso", El País, 6 de diciembre de 2000. 
diciembre, titulado "Indulto muy particular», concluye que el Gobierno no puede nombrar jueces.

\subsection{El Auto de la Sala Segunda del Tribunal Supremo $y$ el requerimiento de incompetencia instado por el Gobierno}

Una vez concedido el indulto, Gómez de Liaño recusó a dos de los magistrados miembros de la Sala Segunda del Tribunal Supremo que debían proceder a aplicar su indulto, Enrique Bacigalupo y José Antonio Martín Pallín, aduciendo que no eran neutrales, puesto que habian participado en el tribunal que le condenó por prevaricación. En El País, Javier Pradera escribe un artículo de opinión titulado «El Gran Recusador" 53 , en el que denuncia las maniobras obstruccionistas, que considera sin fundamentación legal y extemporáneas. El Mundo, en su editorial del 21 de diciembre de 200, titulado «Nuevas Maniobras contra Liaño", defiende que éste tiene derecho a un examen justo e imparcial de su indulto, para añadir: "Es lo menos que se puede pedir en un caso que, desde el principio, tuvo mucho más de ajuste de cuentas que de proceso judicial». Sin embargo, la Sala Penal del Tribunal Supremo rechazó por medio de un auto aprobado por unanimidad de sus doce miembros la mencionada recusación de Liaño contra dos de sus magistrados en base a los argumentos citados, siendo de destacar que la LOPJ no prevé la recusación en el trámite de aplicación del indulto.

El 18 de enero, el Pleno de la Sala Segunda, interpretó por Auto (Al) que no procedía el reingreso inmediato de Liaño a la carrera judicial, puesto que la pena ya había sido cumplida y no podía indultarse. Por consiguiente, le incapacitaba para obtener la condición de juez durante quince años. Con el Decreto de indulto Liaño tendría que esperar cinco años (cuando se cancelasen sus antecedentes penales) para solicitar su reingreso en la carrera judicial. De este modo ejecutó el indulto sólo sobre los 15 años de inhabilitación, no sobre el resto del contenido del Decreto.

Esta decisión judicial no agrada al Gobierno, ya que éste sostiene la tesis de que el control del indulto lo debería haber realizado la SalaTercera delTS, y que el tribunal sentenciador sólo puede negarse a ejecutar el indulto en los casos previstos en el art. 4 de la ley del indulto, artículo que no prohíbe indultar penas ejecutadas. En esta lógi-

53 Javier Pradera, "El Gran Recusador», El País, 27 de diciembre de 2000. 
ca, el Tribunal sentenciador debe aplicar el indulto, pero no ejercer un control corrector.

Ante el requerimiento del Ministerio de Justicia presentado el 7 de febrero, el Pleno de la Sala Segunda del TS sostuvo en auto del 13 de marzo de 2001 (ARI), por diez votos a favor y uno en contra, la imposibilidad de que el Tribunal de Conflictos de Jurisdicción «competente únicamente en materia de deslinde competencial, revise $\mathrm{y}$ anule la interpretación de la legislación penal" hecha por elTS. Además entendía que al conceder sólo una parte del indulto tomó una decisión estrictamente penal y se limitó a aplicar los arts. 4 de la ley del indulto y 42 del CP para determinar si la pena de inhabilitación impuesta a Gómez de Liaño estaba ya cumplida.

Desde El País se vertieron opiniones críticas a la pretensión gubernamental de plantear un conflicto de jurisdicción, conflicto regulado en la Ley Orgánica 2/1987, de 18 de mayo. Así, Javier Pérez Royo considera que uel Tribunal Supremo no ha puesto en cuestión la jurisdicción o competencia del Gobierno para dictar el real decreto de indulto de don Javier Gómez de Liaño, sino que se ha limitado únicamente a considerar que dicho real decreto es parcialmente inaplicable porque no se ajusta a lo que dispone la ley ${ }^{54}$. Por su parte, Joan J. Queralt critica la denominación de conflictos jurisdiccionales, sostiene que no nos encontramos ante este supuesto y afirma que debería recurrirse al conflicto de atribuciones entre órganos constitucionales ante el Tribunal Constitucional, recordando que en este caso no es el poder judicial uno de los legitimados para interponerlo sino el CGPJ. El autor entiende que el Gobierno basa su requerimiento en el art. 38 LOPJ, el cual no es aplicable porque hace referencia a los conflictos que surjan entre los órganos judiciales y la administración (no el Gobierno, como es aquí; el indulto no es una competencia de la administración). Además, considera que se trata de una resolución firme delTS, no de una pretensión de un órgano judicial, con lo cual no le es aplicable lo que prevé el art. 7 de la ley del TCJ (eventual conflicto al entrometerse el juez en la ejecución gubernativa). Por último, afirma que el TCJ no es un órgano jurisdiccional55. de 2001.

54 Javier Pérez RoYo, "¿Conflicto de jurisdicción?", El País, 10 de enero de 2001.

55 Joan J. Queralt, “¿Conflictos jurisdiccionales?», El País, 8 de mayo 
Manuel Atienza, en Información, entiende que las razones que expone el Gobierno para plantear el conflicto de jurisdicción van más allá de las intenciones declaradas, que el autor resume con un «probar suerte» ${ }^{56}$.

Pero la polémica del ARI no discurrió solamente en los aspectos de fondo, puesto que en El País, Javier Pradera ${ }^{57}$ rebate la acusación de EI Mundo de que diversas sentencias del siglo XIX que el propio ARI cita para afirmar su competencia, estaban mal citadas. Considera que es un mero error de transcripción, que es clarísima la competencia del TS, especialmente porque se trata de una resolución firme, y que el Gobierno y El Mundo pretenden deslegitimar al Tribunal Supremo ${ }^{58}$.

El Mundo, en un resumen de los avatares del caso, publicó un artículo de Cristina López Schlichting con un título muy sugerente: "Dos bodas y un "funeral" ", y un subtítulo muy explicativo: "Ésta es la película de la condena de Liaño, en manos, entre otros, del ex marido de su mujer "59. Los editoriales del diario El Mundo fueron avivando la polémica con títulos como "Cuando la justicia la dicta el ex marido de tu mujer" (9/01/01), "Un nuevo "gobierno" de España usurpa al de Aznar el ejercicio del derecho de gracia” (22/01/01), "¿Prevaricación o error de Ancos, Bacigalupo y Pallín?" (23/01/01) o "Los erráticos criterios de la Sala Segunda» (6/02/01). Estas descalificaciones son contestadas por Javier Pradera en El País al considerar que El Mundo hacía uso del amarillismo con estos titulares, invadiendo la vida privada del ex marido de María Dolores Márquez de Prado, para añadir que «si las tropas de asalto hitlerianas rompían los huesos de sus adversarios y los camisas negras mussolinianos les hacian tragar aceite de ricino, esta nueva variante mediática de fascismo chantajea a las víctimas con la amenaza de arrastrarles por el fango y de castigarles si desobedecen ${ }^{60}$. Ante estas luchas periodísticas, y por su incidencia en el honor e intimidad de diversos magistrados del Tribunal Supremo, el Consejo General del Poder condenó el 10 de enero del 2001 las «descalificaciones personales" lanzadas por algunos medios de comunicación.

56 Manuel ATIENZA, "La indeterminación del Derecho y el caso Gómez de Liaño", Información, 16 de enero de 2001.

57 Javier PRADERA, "El detective chapucero», El País, 29 de abril de 2001.

58 Sobre este affaire, véase las opiniones divergentes en EI Mundo y EI País del 24 de abril de 2001.

59 Cristina LOPEZ SCHLICHTING, "Dos bodas y un "funeral" ", El Mundo, 14 de enero de 2001.

60 Javier Pradera, "Aceite de ricino", El País, 14 de enero de 2001. 


\subsection{La Sentencia del Tribunal de Conflictos de Jurisdicción}

Poco antes de la sentencia del Tribunal de Conflictos de Jurisdicción (STCJ) se volvieron a calentar los motores periodísticos. $A B C$ afirma en su editorial del 4 de junio de 2001, que el conflicto de jurisdicción es un mecanismo adecuado para defender las competencias del Gobierno, el cual ha actuado siempre por responsabilidad institucional. Critica las maniobras del CGPJ, dirigidas por los que considera vocales de orientación socialista, de intentar plantear un conflicto de atribuciones entre órganos constitucionales que finalmente no prosperó. En sus páginas de información nacional hace referencia a «dos precedentes muy sonados" de sentencias delTCJ (un caso de extradición y el de los papeles del CESID), quizás para dar a entender que el procedimiento ante este órgano es algo normal y correcto, que declararon en el primer caso que la competencia corresponde al Poder Judicial y en el segundo al Gobierno. Sin embargo, más tarde informa que «no es la primera vez que un Ministro plantea un conflicto de jurisdicción a un órgano judicial, pero si a una Sala entera del Supremo».

La STCJ 6/2001, de 13 de junio, afirma que Liaño perdió su condición de magistrado a consecuencia de la ejecución de la sentencia que le condenó a 15 años por prevaricación, por lo que su reingreso en la carrera judicial reclama una decisión del CGPJ y el reingreso no podría producirse hasta que tenga cancelados sus antecedentes penales, dentro de unos cinco años, de acuerdo con lo establecido en los arts. 380 y siguientes de la LOPJ (Liaño lo tendrá que solicitar al CGPJ una vez cancelados los antecedentes penales). El plazo de cancelación de antecedentes de las penas graves es de 5 años a partir de la fecha del indulto (art. 136 CP). En el caso de Liaño se cumplirá el 21 de diciembre de 2005.

Un elemento a tener en cuenta en este momento es la futura renovación de los vocales del CGPJ, en aplicación de lo dispuesto en la Ley Orgánica $2 / 2001$, de 28 de junio, en el que con el nuevo sistema habrá una mayoría de representantes de jueces conservadores propuestos por la Asociación Profesional de la Magistratura y por el PP, que podrían ahorrarle el trámite de los 5 años de espera para la cancelación. Así podría interpretarse el voto particular concurrente formulado por los Magistrados José Luis Manzanares Samaniego y Antonio Pérez-Tenessa, que no hacen referencia ni al art. 380 LOPJ ni al papel del CGPJ.

Por su parte, El Mundo, en su editorial del día 13 de junio titulado "Liaño recupera la toga", alaba la resolución por unanimidad del TCJ y defiende la actuación dentro de la "estricta legalidad" del 
Gobierno, critica el "corporativismo", "sectarismo" y "afán de venganza» de la Sala Segunda del TS. Entiende también que el CGPJ ha de aplicar el indulto en los propios términos del decreto, para afirmar a continuación: "El grupo periodístico que no perdona a Liaño la osadía de investigar a su propietario lanzó ayer de nuevo la intoxicación de que el juez sancionado debe esperar cinco años antes de volver a la carrera judicial. Es sencillamente una falsedad. El fallo del Tribunal de Conflictos no dice nada de ello porque, entre otras cosas, la exigencia de rehabilitación sólo se aplica a jueces que hayan sido expulsados de la carrera por haber sido sentenciados con penas privativas de libertad. Ni Liaño ha sido expulsado ni ha sido sancionado con este tipo de penas. Puede volver a obtener destino cuando él lo solicite».

EITCJ considera que la Sala Penal delTS no era competente para revisar el alcance del indulto, sino que en todo caso le hubiese correspondido a la jurisdicción contencioso-administrativa. EITCJ afirma que el indulto "no es un acto declarativo de derechos" y que la ley del indulto encomienda la aplicación de la gracia al tribunal sentenciador, que el Gobierno no realizó una "manifiesta infracción" de la ley que habilitara al tribunal sentenciador a realizar un control de legalidad como así lo hizo. Ante ello, los magistrados del Supremo y el sector del CGPJ crítico con el fallo consideran que elTCJ se ha excedido al enmendar al TS. EI TCJ señala en su sentencia que el Gobierno no cometió "manifiesta infracción" de la ley del indulto y que el TS no debió ejercer un control de legalidad sobre el indulto a Liaño. Admite que la sentencia que le condenó le hizo perder la condición de juez, que el Gobierno es competente para fijar el alcance del indulto y reintegrarlo a la judicatura, aunque el reingreso exige una decisión del CGPJ. En este momento, su vicepresidente, Luis López Guerra, dijo que la resolución del conflicto es "muy grave porque está poniendo en duda la posición constitucional del Supremo" y que no se puede imponer al Consejo una "decisión que no esté basada en la Constitución, en la ley y en la interpretación del Tribunal Supremon" ${ }^{61 .}$

Comentando la STCJ, Francesc de Carreras, en El Periódico de Cataluña, sostiene que con la intervención delTCJ se ha vulnerado el principio de separación y equilibrio de poderes propio de todo Estado de Derecho. Considera que elTCJ no puede decidir sobre el fondo del asunto, sino sólo dirimir si una determinada cuestión le corresponde al poder ejecutivo o al poder judicial. De acuerdo con el art. 31 de la 
ley del indulto, la competencia está clara: la aplicación del indulto le corresponde al tribunal sentenciador. Nadie pone en duda que la potestad de indultar le corresponde al Gobierno. Lo que se discute es la aplicación del mismo: elTS entiende que la pena se cumple entera con la mera ejecución de la sentencia, y el Gobierno que sólo se ha cumplido una parte de la pena y que el indulto afecta al resto que queda por cumplir. Ambas interpretaciones "tienen fundamentos razonables", pero la crítica del autor se dirige contra la sentencia del TCJ que ha ido más allá de su única competencia, esto es, determinar quien tiene competencia para aplicar el indulto. Considera que elTCJ debiera haber inadmitido el recurso del Gobierno o haberlo desestimado en su sentencia, ya que el art. 4 de su ley reguladora dice que su función es limitarse a la defensa de la "esfera de competencia» de las partes. El autor recuerda que la ruptura con el principio de división de poderes ya se había producido con ocasión de la concesión del indulto, puesto que indicaba en su texto cómo se debía aplicar, aspecto éste que fue corregido por elTS y que ahora elTCJ lo ha vuelto a vulnerar. El autor propugna, finalmente, que el Ministerio fiscal o el Defensor del Pueblo presenten un recurso de amparo ante el Tribunal Constitucional ${ }^{62}$.

El diario $A B C$, en su editorial del día 13 de junio de 2001, bajo el título "El Gobierno tenía razón", elogia la responsabilidad del Gobierno al plantear el conflicto porque así se ha respetado el principio de división de poderes, califica alTCJ como órgano jurisdiccional, que no judicial, entiende que hay que despersonalizar la controversia entre el Supremo y el Gobierno, criticando las primeras reacciones del PSOE y de la "izquierda judicial», para acabar sosteniendo que "el Tribunal de Conflictos consolida la competencia del Consejo General del Poder Judicial para resolver sobre el reingreso de Gómez de Liaño en la carrera judicial, en concreto, si dicho reingreso es inmediato o queda aplazado a la cancelación, en 2005, de los antecedentes penales. Pero estas son cuestiones que, en última instancia, incumbe a Liaño discutir con el Consejo».

El propio Gómez de Liaño declaró al diario El Mundo que la espera de cinco años haría el indulto "inoperativo" ${ }^{63}$.

Javier Pradera ${ }^{64}$, en El País, afirma que la mencionada sentencia «invade ilegalmente el territorio confiado al Poder Judicial por la

62 Francesc de CARreras, "ElTribunal del "caso Liaño" no es competente", El Periódico, 15 de junio de 2001.

63 El Mundo, 15 de junio de 2001.

64 Javier Pradera, "La deuda semipagada», El País, 17 de junio de 2001. 
Constitución y satisface sólo a medias la petición del Gobiernon. Considera también que se trata de "un fallo capaz de invalidar el auto del Supremo del 18 de enero pero de confirmar a la vez el núcleo de su argumento", ya que el TCJ admite que Liaño ha perdido la condición de magistrado a consecuencia de la ejecución de la sentencia penal porque el derecho de gracia no borra los antecedentes penales y por tanto tendrá que aguardar hasta finales del año 2005 para ser reintegrado en la magistratura. Resalta las interferencias políticas del caso y critica que el asunto se haya sometido al TCJ, que no es un órgano judicial (por su composición mixta de jueces y consejeros de Estado). Además afirma que el TCJ ha vulnerado varios preceptos de su ley reguladora. La sentencia se pronuncia a favor del control de los indultos por la jurisdicción contencioso-administrativa, sin descartar un cierto control de su ejecución por la jurisdicción penal. El art. 7 de la Ley del TCJ, de 1987, prohíbe plantear conflictos de jurisdicción uen los asuntos judiciales resueltos por auto o sentencia firme", y el art. 17 dice que el tribunal se ha de limitar a indicar a quién le corresponde la jurisdicción controvertida sin entrar en el fondo del asunto, elTCJ pretende revisar una decisión del Tribunal Supremo encomendando al CGPJ la tarea de llevar a cabo el reingreso en la carrera judicial una vez que se hayan cancelado sus antecedentes penales. El articulista acaba afirmando que Aznar no ha podido saldar del todo su deuda con Liaño, porque el Estado de Derecho permite casi todo, pero no todo ${ }^{65}$.

También desde EI País, Eduardo Haro Tecglen hace una refiexión sobre la instrumentalización de Liaño al servicio de los intereses que había detrás del "caso Sogecable" y "la solidaridad de los suyos" hasta el final ${ }^{66}$. Javier Pradera realiza unas consideraciones generales sobre el síndrome de La Moncloa que aqueja a los presidentes del Gobierno y que tiene en el "caso Liaño" una de sus manifestaciones ${ }^{67}$. Nos parecen ilustrativos los títulos de estos dos artículos ("El juececillo valiente» $y$ «EI ventilador fétido») para observar la posición de este periódico.

\subsection{A modo de conclusión}

El presente caso se encuentra condicionado por una serie de elementos de tipo familiar (por ejemplo, se da la circunstancia de que un

65 Javier Pradera, "La deuda semipagada", El País, 17 de junio de 2001.

66 Eduardo HAROTECGLEN, "El juececillo valiente», El País, 20 de junio de 2001.

67 Javier Pradera, "El ventilador fétido", El País, 20 de junio de 2001. 
hijo de Jaime Campmany está casado con una hermana de Márquez de Prado, actual esposa de Gómez de Liaño, así como que el ex marido de aquélla es miembro de la Sala Penal del Tribunal Supremo), y por intereses económicos, mediáticos y políticos. Es un asunto muy enmarañado, como pone de manifiesto que hay un proceso abierto por injurias y calumnias a Liaño, por unos artículos publicados en el diario Ya de Madrid, entre noviembre de 1997 y febrero de 199868, que se encuentra visto para sentencia (EI Mundo, 5 de mayo de 2001), que el PSOE recurra alTC la denegación de comparecencia en el Congreso de los Diputados del presidente del CGPJ, para dar explicaciones sobre el caso, que fue solicitada por la vía de urgencia después de la concesión del indulto (EI País, 7 de mayo 2001), o que Mario Conde, cuyo abogado es el hermano de Javier Gómez de Liaño, por medio de Banesto había controlado acciones del diario El Mundo (4\%) y de la revista Época (50\%), entre otros medios de comunicación.

La concesión del indulto a Gómez de Liaño desató, como hemos podido observar, una encendida polémica entre dos bandos, principalmente por medio de sus buques insignia, El País y El Mundo. Sin embargo, el "caso Liaño" ha abierto las puertas a los juristas para realizar reflexiones operativas de cara a analizar críticamente la vigente y vetusta ley del indulto así como para revisar las condiciones en las que actúan el Gobierno y los jueces. Las desafortunadas declaraciones del Ministro de Justicia en una sesión de control del Gobierno en el sentido de que el indulto no era controlable judicialmente porque estaba firmado por el Rey69, ponen de relieve la necesidad de racionalizar y ubicar correctamente este instituto en el ordenamiento constitucional español.

\section{Aspectos del "caso Liaño» que ponen de manifiesto las deficiencias de la actual ley del indulto}

El indulto a Gómez de Liaño ha puesto de relieve que ciertos aspectos de la Ley del indulto que parecían incontrovertidos pueden

68 En aquella época estalló el caso del presunto vídeo personal de Pedro J. Ramírez, de cuya instrucción se encargó Gómez de Liaño, aunque un juez ordinario ya había iniciado las diligencias judiciales. Gómez de Liaño finalmente se abstuvo, al conocer de la existencia de un vídeo sobre él mismo. de 2000.

69 Véase la información reproducida en La Vanguardia, de 14 de diciembre 
llegar a ser problemáticos, cuando no manejables o moldeables a voluntad del Gobierno. Nos vamos a centrar en el art. 4 de la Ley de 1870: «El indulto podrá ser total o parcial. Será indulto total la remisión de todas las penas a que hubiese sido condenado y que todavía no hubiese cumplido el delincuente. Será indulto parcial la remisión de alguna o algunas de las penas impuestas, o de parte de todas las que hubiese incurrido $y$ no hubiese cumplido todavía el delincuente. Se reputará también indulto parcial la conmutación de la pena o penas impuestas al delincuente en otras menos graves». De este artículo destacaremos, por un lado, la separación de los conceptos indulto total e indulto parcial $y$, por otro, la prohibición de indultar penas ya cumplidas. La distinción entre indulto total o parcial tiene relevancia porque el art. 11 de la misma ley indica que: «El indulto total se otorgará a los penados tan sólo en el caso de existir a su favor razones de justicia, equidad o utilidad pública, a juicio del Tribunal sentenciador". Lo que supone la prohibición de indulto total con informe negativo del Tribunal sentenciador.

En diversas ocasiones se ha argumentado que el Decreto de indulto a Liaño no había infringido el artículo 10 de la Ley de indulto porque establecía una condición (no volver durante 25 años a la Audiencia Nacional) y porque no indultaba la pena de multa. En cuanto al primer argumento, el Tribunal de Conflictos de Jurisdicción declara que es el Consejo General del Poder Judicial el órgano competente para dar cumplimiento al reingreso en la carrera judicial, sin que el Gobierno puede dar instrucciones en este sentido. Desmontado este argumento, no queda más que recurrir a la inclusión de la pena de multa en el decreto de indulto y en consiguiente no considerar que se han indultado "todas las penas a que hubiese sido condenado" (art. 4). Este hecho muestra cómo el Gobierno puede sortear una limitación legal, como es la prohibición de indultos totales con informe desfavorable delTribunal sentenciador, de maneras muy diferentes, debido a la laxitud del art. 4 de la misma Ley. Asi en una condena de 15 años se puede indultar 14 años y 364 días con informe desfavorable del Tribunal sentenciador porque no estariamos ante un caso de indulto total. Este ejemplo, y lo sucedido en el "caso Liaño», muestra que los conceptos de indulto parcial e indulto total se convierten en conceptos juridicos a determinar por el Gobierno.

Por otro lado, de la lectura del art. 4 de la Ley de indulto se desprende claramente la prohibición de no indultar penas ya cumplidas. Tanto es así que, como hemos comentado, en el "caso Liaño" hubo muchísimos intentos de justificar que la pena de prevaricación no había sido cumplida, admitiendo implícitamente que el Gobierno tie- 
ne en este precepto un límite claro en la concesión de indultos. No obstante, tanto los firmantes del voto particular al Al como en la STCJ se reconoce expresamente que Gómez de Liaño ha perdido la condición de magistrado, es decir, que una parte de la condena ya está cumplida. Se puede considerar que la doctrina (escribiera en el diario que fuere) estaba de acuerdo en el hecho de que si se consideraba que Gómez de Liaño había perdido la condición de magistrado esta pena ya no se podía indultar. El tenor literal del precepto es claro al requerir del Gobierno el indulto de penas "que todavía no hubiese cumplido el delincuente". Por el contrario, el Tribunal de Conflictos de Jurisdicción cambia el nivel de incumplimiento del citado precepto legal para que los Tribunales puedan controlar un Decreto de indulto en este aspecto: “Pese a todo ello es innegable que, atendiendo tanto al principio de legalidad como al de oficialidad característico de la jurisdicción penal, constituye una exigencia derivada de la misma función atribuida alTribunal de esa jurisdicción con relación a la ejecución de la sentencia - artículo 117.3 de la Constitución - en la que incide el indulto, el admitir que pueda ejercer un control de la aplicación del mismo en determinados y concretos supuestos, en los que se haya producido una manifiesta vulneración de la legalidad". De lo que se deriva que para el Tribunal de Conflictos de Jurisdicción la pérdida de la condición de funcionario no es una manifiesta vulneración de la prohibición de indultar penas ya cumplidas.

Por último cabe hacerse también eco del artículo 16 de la Ley de indulto donde, después de haberse declarado en el artículo anterior que son condiciones tácitas de todo indulto que no se cause perjuicio a tercera persona y que haya sido oída la parte ofendida en los denominados delitos de privados, indica que «podrán además imponerse al penado en la concesión de indulto cuantas condiciones que la justicia, equidad o utilidad pública aconsejen". En numerosas ocasiones, entre ellas en el indulto a Gómez de Liaño, se impone como condición que no vuelva a cometer delito doloso durante el tiempo de normal cumplimiento de la condena. Esta condición per se no trae más problemas. Más polémica es la prohibición impuesta a Gómez de Liaño de no poder volver durante 25 años a la Audiencia Nacional, que luego ha sido de alguna manera cuestionada por el Tribunal de Conflictos de Jurisdicción. La literalidad del artículo trascrito permite dar a entender que el alcance de las condiciones que puede imponer el Gobierno es ilimitado. No obstante, en un Estado de Derecho, las condiciones que un Gobierno imponga a un penado no pueden ser más gravosas que la condena ni interferir en competencias de los otros órganos constitucionales. 
Las polémicas judiciales que han sucedido a la concesión del indulto a Gómez de Liaño han puesto en evidencia la urgencia de un cambio legislativo ante unos preceptos legales anticuados, que un Gobierno puede llegar a utilizar a su conveniencia.

\section{PROPUESTAS PARA LA REFORMA DE LA LEY DEL INDULTO}

Francesc de Carreras y Montserrat Comas d'Argemir han destacado el carácter vetusto de la Ley provisional de 1870 actualmente vigente $^{70}$. Hay quien considera, sin embargo, que el hecho de haber pervivido desde su aprobación con diversos avatares históricos y diversos regímenes políticos muestra una «sabiduría no siempre cabalmente apreciada» ${ }^{71}$.

Habiendo esbozado los presupuestos para que el indulto tenga cabida en un Estado de Derecho moderno es necesario que éstos se plasmen en una nueva regulación legal del indulto. A nuestro entender, la aprobación de la Constitución de 1978 reclamaba implícitamente una nueva regulación legal del indulto más acorde con los principios y normas constitucionales. Si bien se produjo una reforma en 1988 ésta fue, desde todos los puntos de vista, insuficiente porque se refería casi exclusivamente a cambios de estilo y nomenclatura, provocados por el paso de los años (sustitución de los vocablos Ministerio de Gracia y Justicia, Gaceta de Madrid, etc.). Pero hay un cambio de fondo que lejos de acercar el texto a los postulados constitucionales lo hace retroceder, a nuestro juicio. Así, las palabras «Decreto motivado y acordado en Consejo de Ministros" se sustituyen por la lacónica expresión

70 Francesc de Carreras Serra, "El indulto en nuestro Estado de Derecho", El País, 12 de diciembre de 2000, y Montserrat COMAS D'ARGEMIR, "El indulto no deshace el delito", El Periódico de Cataluña, 5 de diciembre de 2000.

71 LINDE PANIAGUa, Enrique, «El indulto como acto de administración de Justicia y su judicialización. Problemas, límites y consecuencias", en Teoría y Realidad Constitucional, ${ }^{\circ}{ }^{\circ} 5,2000$, pág. 165 . Este autor también se ha mostrado crítico con la actual regulación legal, reconociendo que se encuentra "entre los que cree que la clemencia en sus manifestaciones, amnistía e indulto, es compatible con el constitucionalismo democrático, situando el nivel de discrepancia en la regulación específica que dichas técnicas reciben en los diferentes ordenamientos jurídicos, así como en la utilización de las mismas", en LINDE PANIAGUA, Enrique, "La clemencia (amnistía e indulto) a la luz de la jurisprudencia de los tribunales Supremo y Constitucional y del Código Penal de 1995", en Boletín de Información del Ministerio de Justicia, núm. 1823, 15 de junio de 1998, pág. 7. 
"Real Decreto" (art. 30 reformado por el artículo tercero de la ley de reforma de 1988), desapareciendo toda mención a la motivación. No obstante, como hemos argumentado, hoy en día, la propia CE exige la motivación de los actos discrecionales, puesto que en otro caso serian actos arbitrarios, vedados constitucionalmente ${ }^{72}$.

Además, al compás del desarrollo de la constitución, se han ido produciendo cambios legislativos que reclamarian reformas puntuales de la Ley de Indulto, como fue la abolición de la pena de muerte en tiempo de guerra (LO 11/1995, de 27 de noviembre) o a la aprobación del actual Código Penal (LO 10/1995, de 23 de noviembre). Sin embargo, la oportunidad no se ha aprovechado.

Pero si ha habido un hecho desde la aprobación de la Constitución que reclame la aprobación de una nueva ley de indulto, éste es, sin duda, como hemos comentado $y$ analizado, la concesión de indulto al magistrado Gómez de Liaño y su posterior polémica.

La nueva regulación legal debería ser, como mínimo, parcialmente orgánica en los aspectos que afecten a la regulación de los derechos fundamentales (art. $81 \mathrm{CE}$ ), en especial el de la libertad deambulatoria ${ }^{73}$, si aplicamos una doctrina no expansiva del alcance de la ley orgánica ${ }^{74}$.

En cuanto a su estructura, la nueva ley, a parte de los tres capitulos existentes ("De los que pueden ser indultados", "De las clases y

72 Aguado Renedo, César, Problemas constitucionales del ejercicio de la potestad de gracia, Civitas, Madrid, 2001, pág. 225, considera inconstitucional la reforma al suprimir la referencia a la motivación, ya que debe darse en todo caso como una exigencia constitucional derivada del art. 9.3.

73 CoRTés BeChIARELLI, Emilio, "Artículo 4", en Comentarios al Código Penal, Edersa, 2000, tomo I, pág. 110, considera que la ley del indulto debería ser una ley orgánica, en su totalidad.

74 Esta doctrina restrictiva se puede consultar en la STC 118/1992, de 16 de septiembre, referida a las normas penales en blanco: «Esta exigencia de Ley formal para las normas penales, que resulta del art. 25.1 CE no implica, por sí sola, la necesidad de que las normas penales hayan de revestir rango de Ley orgánica (STC 25/1984). Pero si existe reserva constitucional a favor de la Ley orgánica, de conformidad con lo dispuesto en el art. 81.1, en relación con el art. $17.1 \mathrm{CE}$, respecto de las normas penales que establezcan penas privativas de libertad". Sin embargo, el propio Tribunal Constitucional ha mantenido una doctrina relativamente expansiva del alcance de la ley orgánica en la STC 160/1986, de 16 de diciembre, al considerar que "el Código Penal, y en general las normas penales son garantía y desarrollo del derecho de libertad en el sentido del art. 81.1 de la CE, en cuanto fijan y precisan los supuestos en que legítimamente se puede privar a una persona de libertad. De ahí que deban tener carácter de Orgánicas». 
efectos del indulto" $y$ "Del procedimiento para solicitar y conceder la gracia del indulton), debería introducir un cuarto dedicado a la aplicación y control del indulto particular. Los principales cambios que proponemos se podrían resumir en cuatro aspectos: más motivación, más objetividad, más control y más regulación.

Nos vamos a centrar en las reformas que tienen relación directa con los problemas de regulación legal que hemos observado analizando el "caso Liaño", citando luego aquellas que también son necesarias para dotar de una coherencia total a la nueva ley, de acuerdo con los postulados constitucionales que hemos definido. Para una mayor estructuración de las propuestas se procederá a la numeración de las mismas.

1. De los que pueden ser indultados: La nueva ley de indulto podría limitar los delitos que son susceptibles de clemencia particular. Desde el momento en que los derechos que son inherentes a la persona son el "fundamento del orden político y de la paz social» (art. 10 (CE), el mayor ataque a estos derechos; el delito de genocidio, podría estar exceptuado del ámbito del derecho de gracia, una vez que el Código Penal considera que es un delito que no prescribe en ningún caso (art. $131.3 \mathrm{CP}$ ) y, por tanto, de una gravedad que ni el paso del tiempo es capaz de borrar. Otros delitos también podrían seguir esta limitación. Así, compartimos con Javier Pérez Royo ${ }^{75}$ la idea que la prevaricación judicial, en tanto que delito cometido por el titular de un poder del Estado, no tendría que poderse indultar a semejanza de lo contemplado en el art. 102.3 CE respecto a los miembros del Gobierno. No obstante, a diferencia del criterio mantenido por el citado autor entendemos que sólo con una reforma legislativa (o constitucional) se puede introducir esta limitación, difícilmente argumentable con el marco jurídico vigente. De esta manera, supuestos como el "caso Liaño» no volverían a repetirse.

Todas estas limitaciones, lejos de ser una reducción de las facultades del Gobierno son una garantía de la primacía de los derechos fundamentales y expresan la sujeción del Gobierno a la Constitución $y$ a las leyes.

2. El arrepentimiento $y$ otras condiciones: El arrepentimiento debe configurarse como un presupuesto para la concesión del indulto, cuanto menos una condición suspensiva ex lege de todo indulto, 
para que el indultado sea consciente que el indulto no es una nueva instancia judicial que le ha borrado el delito. El delito subsiste igual que la ley que lo previó y el derecho de gracia no lo cuestiona, y por lo tanto el indultado tampoco debe hacerlo. En esta misma línea, como condición suspensiva ex lege se tendría que introducir también el reconocimiento por el penado de la existencia de delito. La forma de exteriorizar y reafirmar la existencia del delito y la vigencia de la norma se produce mediante el arrepentimiento. EI ITS declara categóricamente que: «Es evidente que el arrepentimiento es uno de los elementos que se debe considerar desde el punto de vista de la prevención general, puesto que el deterioro de esta función de la pena sería intolerable si se indultara a personas que se niegan a reconocer la vigencia de la norma que han violado conscientemente». Con esta medida, no se darían situaciones como las planteadas en el "caso Liaño", donde es notorio que el ex juez Gómez de Liaño no está arrepentido del delito cometido (la existencia del cual tampoco reconoce).

Como condición resolutiva ex lege se debería exigir que el indultado no vuelva a cometer delito doloso durante el tiempo de normal cumplimiento de la condena. En el "caso Liaño" hemos visto cómo el Gobierno introducía este requisito, aunque no debería dejarse a su libre arbitrio la introducción de esta condición.

3. Redefinición de las diferencias entre indulto total e indulto parcial: Actualmente la diferencia entre indultos totales y parciales tiene su razón de ser en la necesidad de informe favorable del tribunal sentenciador aduciendo razones de justicia, equidad o utilidad pública para los indultos totales. No obstante, este límite se puede salvar fácilmente. Como ya se ha señalado, si la condena es a diez años de prisión y existe un informe desfavorable del tribunal sentenciador, se puede indultar a nueve años y medio (o tensando las cuerdas a diez años menos un día) y se evitaría la necesidad de contar con el informe favorable. En la polémica del "caso Liaño" se ha argumentado que cómo el DI no hacía ninguna consideración a la pena pecuniaria nos encontraríamos ante un indulto parcial ó que con la limitación de ejercer durante veinticinco años en la Audiencia Nacional se había producido una conmutación de la pena. Por lo tanto, entendemos que es preciso definir los límites entre indulto total e indulto parcial, para huir de equívocos y para evitar que la diferencia no tenga ninguna virtualidad para el Gobierno. Se debería considerar indulto total en dos casos, a saber: a) cuando se remiten todas las penas, y b) cuando se remite la totalidad de la pena principal o más del cincuenta por ciento del tiempo de la condena. 
4. Informes: Se deben redefinir los informes previstos en la actual regulación. El art. 25 hace una enumeración, que a primera vista puede parecer exhaustiva, de menciones que tiene que hacer el tribunal sentenciador, pero no dejan de ser obviedades si se entrega testimonio de la sentencia y la hoja histórico-penal (circunstancias del delito, posibles delitos precedentes) o datos que difícilmente puede conocer (conducta posterior a la ejecución, indicios de arrepentimiento). En cambio se deberian introducir elementos como la valoración de la poca entidad del delito, efectos derivados de la duración del proceso, etc. Asimismo, para dar mayor objetividad a la concesión de los indultos podría recuperarse el informe del Consejo de Estado en caso de que el informe del Tribunal sentenciador no fuera favorable. Por otro lado, si la petición de indulto parte del Tribunal sentenciador, el informe de prisiones o del Subdelegado del Gobierno puede no ser necesario $^{76}$.

El informe favorable del Tribunal sentenciador debería ser necesario no sólo para los actuales indultos totales, sino también para los parciales que indulten más de la mitad del tiempo de la condena. Además debe ser siempre obligatoria la emisión del informe por el Tribunal sentenciador, a diferencia de lo previsto actualmente en el art. 29 de la Ley del indulto.

5. Motivación: Se debe volver a añadir en la Ley del indulto la necesidad de motivación de los decretos de indulto, puesto que aunque ahora los principios constitucionales ya exigen la motivación de los actos del Gobierno, incluso los discrecionales, los decretos de indulto simplemente indican "teniendo en cuenta las circunstancias que concurren en los hechos" o el más el escueto e insuficiente utilizado en el DI a Gómez de Liaño "visto el expediente de indulto".

Se puede establecer incluso un numerus clausus de motivos que puede aducir el Gobierno para otorgar el derecho de gracia. En este sentido defendemos la posición mantenida por Montserrat Comas d'Argemir, "en el futuro, y de acuerdo con la necesaria separación de poderes de nuestro Estado de derecho, debería modificarse la ley a fin de reservar los indultos sólo para aquellos supuestos desgraciados de lentitud judicial en los que el transcurso del tiempo ha hecho inútil el cumplimiento de una pena para personas plenamente resocializadas $y$, en último extremo, para aquellos casos en los que así lo solicitase

76 En el mismo sentido, Cortés BeChIARELLI, Emilio, "Artículo 4», en Comentarios al Código Penal, editorial Edersa, 2000, tomo I, pág. 111. 
el propio tribunal juzgador si considera que la pena es excesiva atendiendo el mal causado y las circunstancias personales del condenado" 77 . Así, las dilaciones indebidas y la resocialización y reinserción de los condenados deben convertirse en dos de los motivos básicos que fundamenten la concesión de indultos.

También tenemos que hacer referencia a las enfermedades terminales ( $y$ dentro de ellas el SIDA como una de las más presentes en nuestras cárceles) como uno de los motivos que deberian introducirse en cualquier numerus clausus que se pretenda realizar.

6. Jurisdicción competente: Se debería establecer claramente qué jurisdicción es la competente para enjuiciar y aplicar las medidas de gracia. Actualmente el artículo 31 de la Ley de Indulto es tajante al afirmar que "la aplicación de la gracia habrá de encomendarse indispensablemente al Tribunal Sentenciadorn, pero según parece desprenderse de la STCJ en el "caso Liaño", los problemas de legalidad que surgieran tendrían que sustanciarse en la Jurisdicción contencioso-administrativa.

7. Aplicación del indulto por los Tribunales: Se debe declarar que el Tribunal sentenciador o el tribunal encargado de la aplicación del indulto no debe ejecutar la concesión de indultos sobre penas ya cumplidas. Asimismo tampoco se deberían ejecutar indultos sobre penas ya prescritas, que no se adaptaran a las condiciones ex lege, que vulneraran prohibiciones legales $u$ otros límites impuestos por la Ley del indulto.

Las anteriores propuestas han surgido al hilo del "caso Liaño", aunque también proponemos otras no directamente relacionadas con el mismo:

- La solicitud del indulto: Debe suprimirse la facultad del Gobierno de "auto-solicitarse" la formación de un expediente de indulto. La separación de poderes queda mejor salvaguardada si el Gobierno decide indultos que otros actores (privados y judiciales) le solicitan.

- Conmutación de penas: La conmutación de la pena principal deberá obtener siempre el visto bueno delTribunal sen-

77 Montserrat COMAS D'ARGEMIR, "El indulto no deshace el delito», El Periódico de Cataluña, 5 de diciembre de 2000. 
tenciador, el cual no daría aplicación a conmutaciones más gravosas aunque el penado estuviese conforme.

- Alcance del indulto: Aparte de destacar que el indulto no se extiende a las costas procesales (art. 9) ni a la indemnización civil (art. 6), debe excluirse la devolución de la pena pecuniaria ya pagada.

\section{BIBLIOGRAFÍA}

Citamos a continuación solamente la bibliografía española más relevante publicada después de la Constitución de 1978 y que ha sido utilizada para la realización del presente trabajo.

Aguado Renedo, César: Problemas constitucionales del ejercicio de la potestad de gracia, Civitas, Madrid, 2001.

LINDE PANIAGUa, Enrique: "El indulto como acto de administración de Justicia y su judicialización. Problemas, límites y consecuencias", en Teoría y Realidad Constitucional, núm. 5, 2000, págs. 161-175.

- "La clemencia (amnistía e indulto) a la luz de la jurișprudencia de los tribunales Supremo y Constitucional y del Código Penal de 1995", en Boletín de Información del Ministerio de Justicia, núm. 1823, 15 de junio de 1998, págs. 5 y ss.

LÓPEZ AGUILAR, Juan Fernando: "Una reflexión a propósito del control parlamentario del ejercicio del derecho de gracia" en Revista de las Cortes Generales, núm. 37, primer cuatrimestre de 1996, págs. 329-342.

LOZANO, Blanca: "El indulto y la amnistía ante la Constitución», en Estudios sobre la Constitución española. Homenaje al profesor Eduardo García de Enterría, Civitas, Madrid, 1991, vol. II, págs. 1027-1051.

LlorCa OrTega, José: La Ley de indulto (Comentarios, jurisprudencia, formularios y notas para su reforma), 2. edición, Tirant lo Blanch, Valencia, 1997.

Martín Pallín, José Antonio: "El derecho de gracia", en Ministerio Fiscal y sistema penitenciario (III Jornadas de Fiscales de Vigilancia Penitenciaria), Centro de Publicaciones del Ministerio de Justicia, Madrid, 1992, págs. 307-322. 
Pérez del Valle, Carlos: "Amnistía, Constitución y justicia material», Revista Española de Derecho Constitucional, núm. 61, enero-abril 2001, págs. 187-206.

ReQueJo PAgÉs, Juan Luis: «Amnistía e indulto en el constitucionalismo español", en Revista Electrónica de Historia Constitucional, http://hc.rediris.es/dos/articulos/html/indulto.htm.

ZÚNIIGA URBINA, Francisco: "Amnistía ante la jurisprudencia (Derechos humanos como límite al ejercicio de la soberanía)", en Revista de Derecho Político, núm. 42, 1996, págs. 371-422. 